\title{
Geomorphologic and hydrogeologic studies for some basins in the area between Abu Ghusun and Bernice, South Eastern Desert, Egypt"
}

\author{
Hassan Saleh Thabet ${ }^{1}$; Mohamed Abd Ellah khaled ${ }^{2}$ and \\ Hassan Ibrahim Hassan ${ }^{3}$ \\ 1- Geol. Dep., Fac. Sci., Al Azhar Univ., Cairo, Egypt. \\ 2- Desert Research Center, El Matarya, Cairo, Egypt.
}

3- Environmental Management, Hurghada, Red Sea Governorate, Egypt.

\begin{abstract}
Geomorphological and hydrogeological investigations were carried out in 7 selected basins in the area between Abu Ghusun and Bernice (Eastern Desert), to evaluate their groundwater potentialities. Seven hydrogeological basins were extensively studied through morphometric analyses. These basins from north to south are Um Al Abas, Abu Ghusun, Ranga, El Reidi, Khashir, Lahami and Mukhit. These basins of second order discharge towards the coastal plain of the Red Sea at the east. The groundwater stored in the lower parts of the wadi filling and the upper fractured bedrock of the wadi (fractured basement rocks). On the other hand, the sedimentary rocks of the down stream parts of the wadis and morpho-tectonic plains contain the Miocene sandstone water bearing formations. Generally, the water bearing formation in the upstream portions of these wadis of limited groundwater potentiality. The thickness as well as the structural elements which affect water percolation and accumulation was defined.

Promising location for digging new groundwater well was recommended in these basins and the results confirmed those obtained from the geoelectric survey in these basins.
\end{abstract}

Keywords: Eastern Desert, Geomorphology, hydrogeology, Abu Ghusun, Hamata, Bernice, Ranga, El Reidi, Khashir, Lahami and Mukhit.

\section{INTRODUCTION}

The water resources represent the greatest difficulty towards the development of desert regions. Special attention should be focused on the future development for groundwater exploration, evaluation are required. In general, desired goals of any management is to obtain the maximum quantity with water quality to meet requirements at least coast. Egypt has turned to the use groundwater to satisfy the growing demand of water. In the last decades, the Eastern Desert of Egypt attracts the attention of numerous investments especially in the fields of tourism, marine sports, diving, fishing, medical treatment, agriculture, petroleum exploration, mining and quarrying.

The present area is previously studied by Samuel and Saleeb-Roufaiel (1977), Abd El Khalik (1978), Samir et al. (1982), Khaled (1995), Aggour (1997), Gheith and Sultan (2002), Al Temamy (2008), Kamal (2010) and Tahoon (2011). The studied area includes some selected basins are terminated at the Red Sea in the east and originate from the high mountainous range (water divide) in the west.

The present investigation is an attempt to evaluate the groundwater potentialities in these basins through geomorphological and hydrogeological approaches. 


\section{Study Area}

The area lies in the extremely arid region of Egypt with very dry summer and relatively cold winter. Yearly precipitation is between $2.75 \mathrm{~mm}$ and $50 \mathrm{~mm}$ and considered as the only source of recharge (Fig. 1). These basins are Um Al Abas, Abu Ghusun, Ranga, El Reidi, Khashir, Lahami and Mukhit. The study area is bounded by latitudes $23^{\circ} 55^{\prime}$ and $24^{\circ} 35^{\prime}$ North and longitudes $34^{\circ} 45^{\prime}$ and $35^{\circ} 35^{\prime}$ East Red Sea coast.

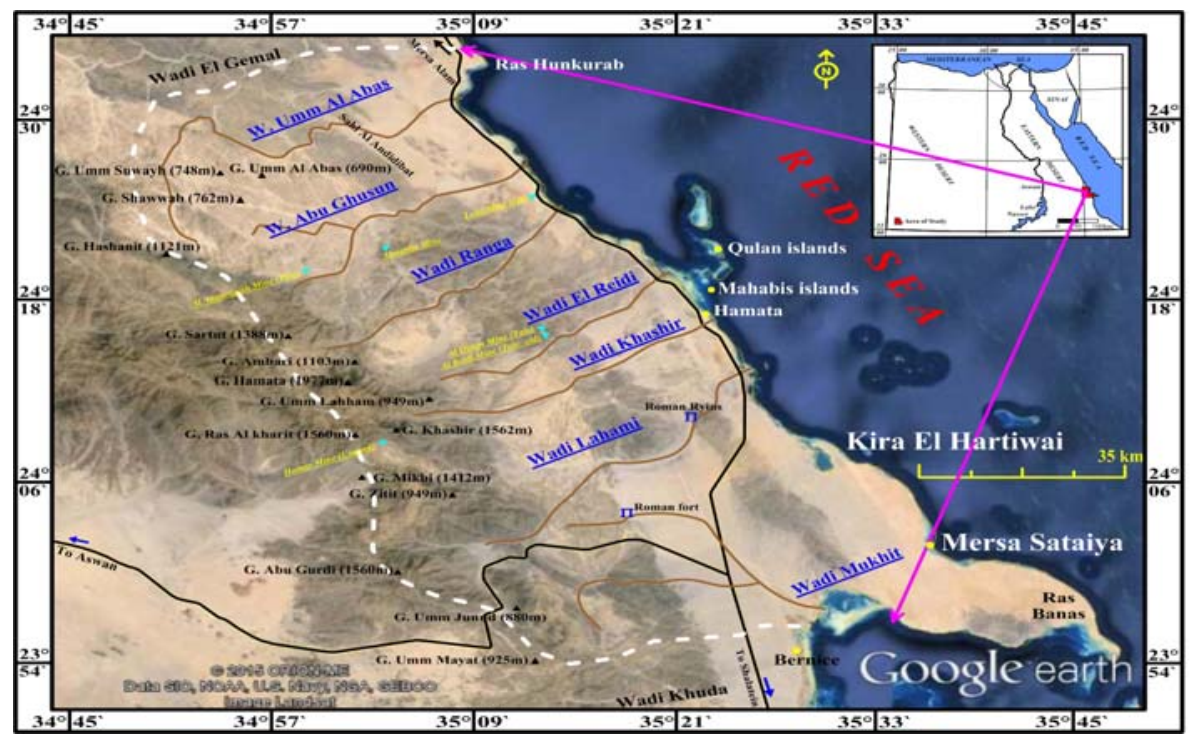

\section{Geomorphology:}

Fig. 1: Map of the study area.

The selected drainage basins are related to the Red Sea system and represented by short, narrow and steeply sloping channels with relatively small catchment's areas. Based on the field observations and topographic maps of different scales (1: 50000, 1: 100000 and 1: 250000), many wadis dissect the area, these wadis initiate from the mountainous terrain and run toward the general eastwardly slope to drain finally in the Red Sea. They are mostly oriented E-W, WNW-ENE, NNW and N-E. The main wadis are considered to be very important as a net of roads in the area and as the main source for underground water (Fig. 2).

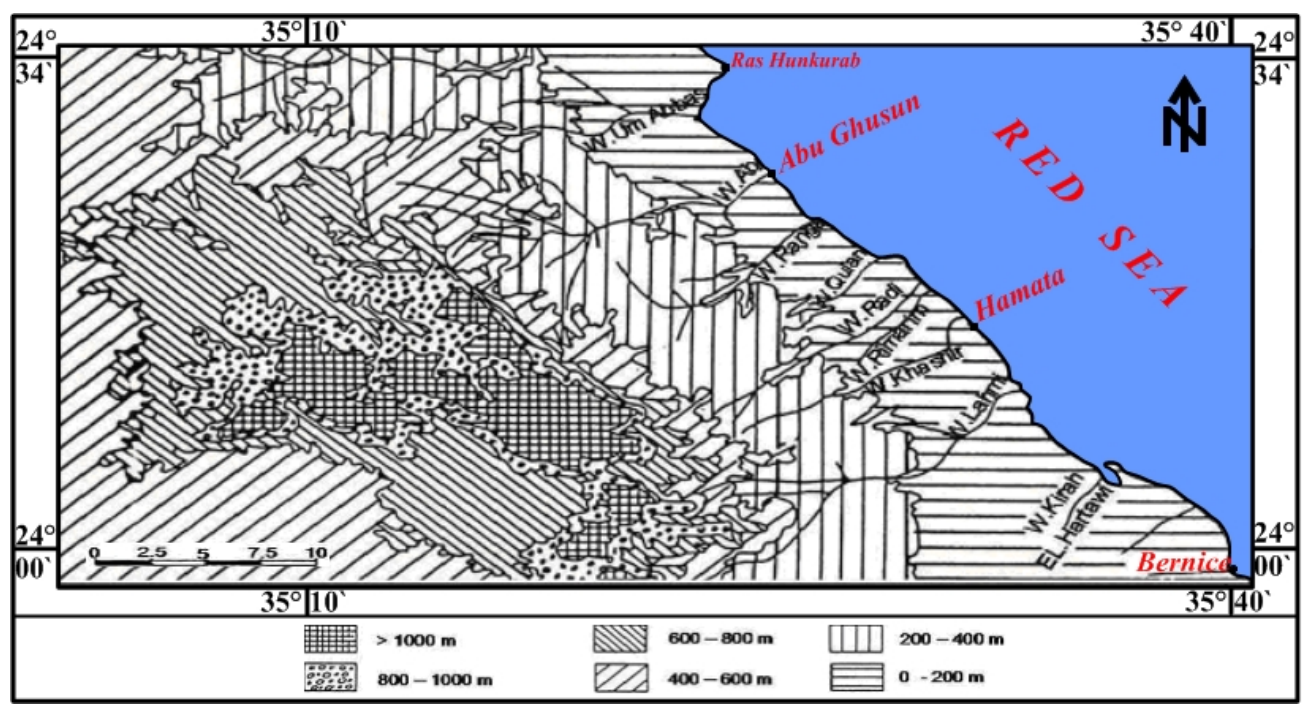

Fig. 2: Topography of the studied area (based on Egyptian Military Survey topographic map scale 1: $250000)$. 


\section{Geologic setting:}

In the area of study, Late Proterozoic Pan-African rocks constitute the main bulk of the mountainous terrain. These are composed of igneous and metamorphic rocks. On the other hand, Pre-Miocene strata are preserved in the downstream portions of the existing basins, e. g. from Um Al Abas to Mukhit and also within the two morpho-tectonic depressions, which are hollowed out in the basement of these basins one at the north (Um Al Abas and Abu Ghusun) and the second at the south (Lahami and Mukhit basins) (Fig. 3). These rocks constitute prominent plateaus. The younger sediments which include Miocene and younger deposits (Pliocene, Quaternary and Recent) exist in the coastal plain and wadi alluvial.

The lithostratigraphic succession in the area under investigation ranges in age from Precambrian to Recent. This succession is divided into the Late Proterozoic basement rocks and the Phanerozoic sedimentary succession. The most common rock units of the sedimentary rocks is the Quaternary sediments, it almost represented as terraces along the coastal area or along the banks of different wadis, it also represented through the coastal sediments and the sand dunes.

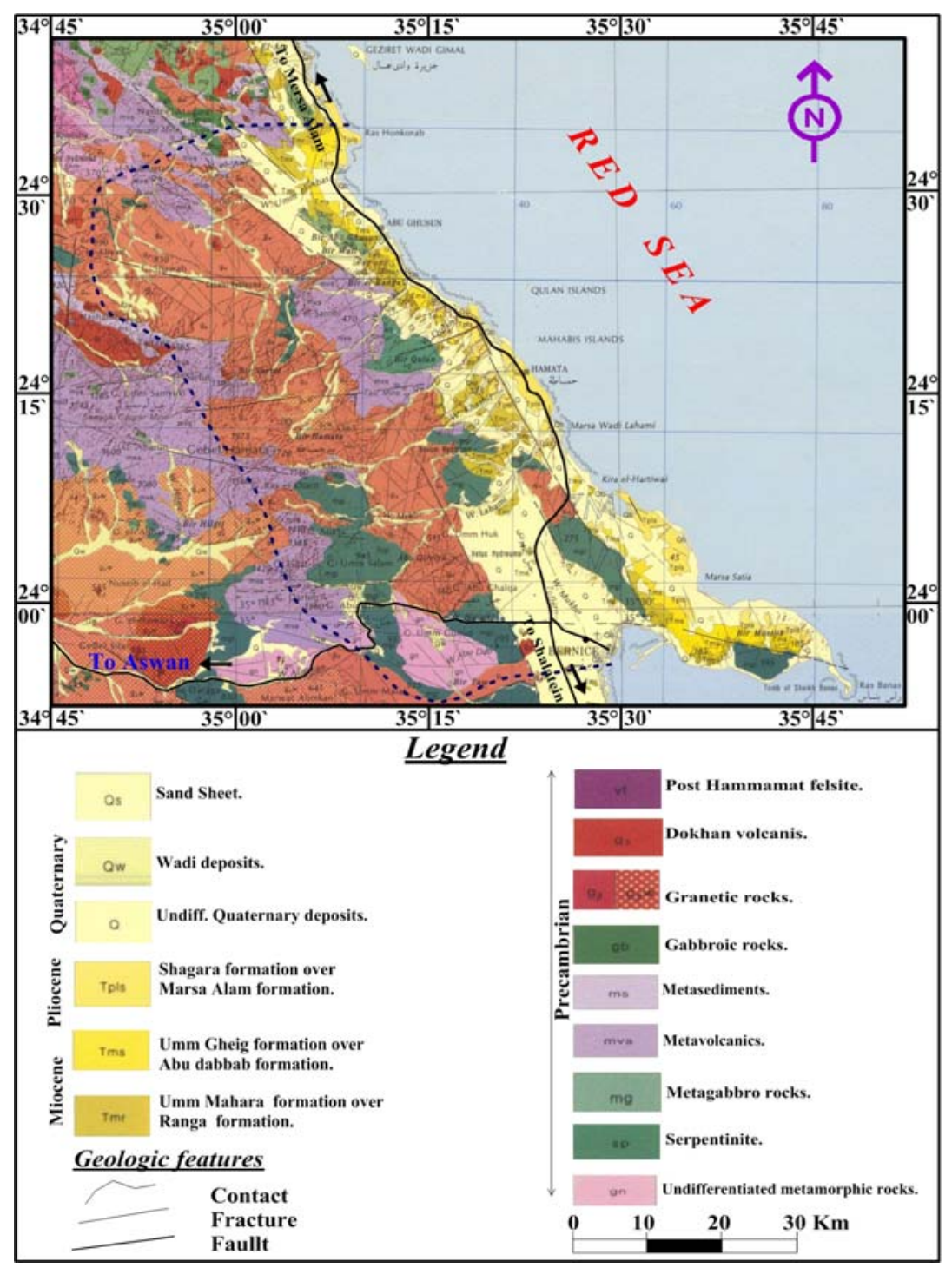

Fig. 3: Geological map of the studied area (Geological Survey of Egypt, 1997). 
The sedimentary succession overlies unconformable the Precambrian rocks from the older to the youngest (Said, 1962), as follows:

1- The Miocene sandstone. 2- The Miocene coral reefs aquifer.

3- The Quaternary sediments.

Structurally, the concerned area has been studied by many others as Said (1962), Tarabili (1964), Issawi (1969 \& 1971), El Ramly (1972), Sabet et al., (1972 \& 1974) and Shazly (1977). Generally, the area of study is commonly dissected by NW-SE set of faults, Parallel to the Red Sea coast (Fig.4). Faults of northeast trends are relatively limited. Different trends of dykes and fracture systems are predominant structures in the basement rocks which have a direct effect on groundwater accumulation (Said, 1962).

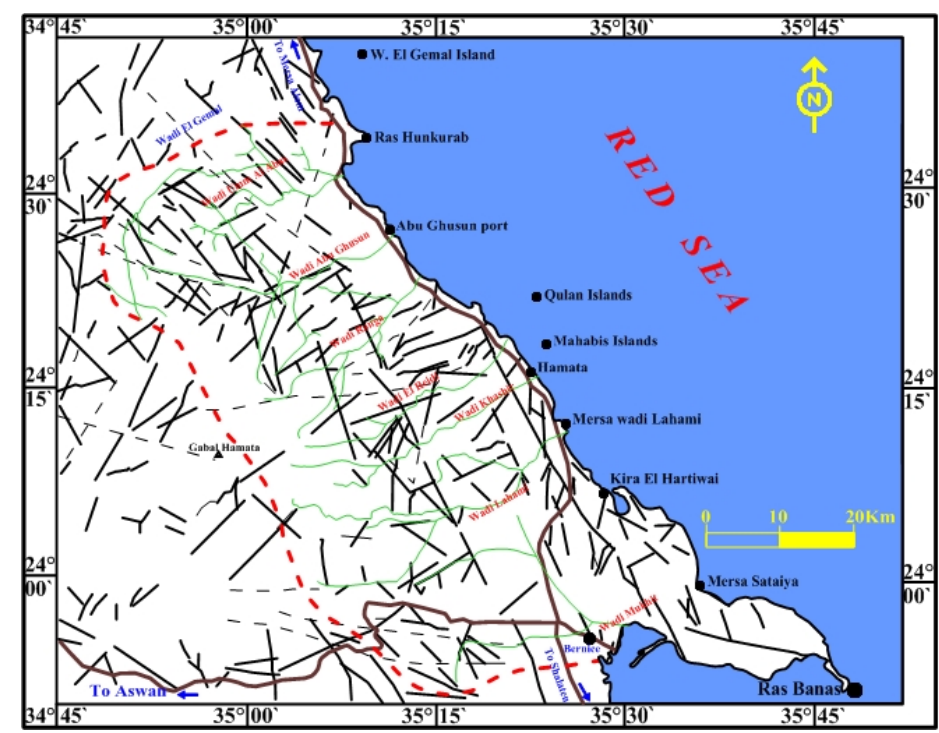

Fig. 4: Structural map of the studied area (based on landsat images, 1:250000), (Modified after Ahmed 2001).

\section{Methodology}

According to Horton (1945), the stream ordering has been determined after Strahler method (1952), the unbranched fingertip tributary is designed as of $1^{\text {st }}$ order; tributary of $2^{\text {nd }}$ order receives branches of tributaries of $1^{\text {st }}$ order, a stream of $3^{\text {rd }}$ order receives one or more tributaries of $2^{\text {nd }}$ order and also perhaps receive $1^{\text {st }}$ order branches. A stream of $4^{\text {th }}$ order receives branches of $3^{\text {rd }}$ order and also of lower orders and so on. Each order has a different color than the other ones. In the studied area the trunk channel for the studied basins has stream order varies from $5^{\text {th }}$ to $7^{\text {th }}$ order. The trunk channel of every basins drains in the Red Sea.

Stream ordering is an important factor to study the morphometric parameters. Generally, stream ordering is a method of assigning a numeric order to links in a stream network. This order was used to identify and classify the types of streams based on their number of tributaries. Some characteristics of streams can be inferred by simply knowing their order. For example, first order streams are dominated by overland flow of water; they have no upstream concentrated flow. Because of this, they are most susceptible to nonpoint source pollution problems and can derive more benefit from wide riparian buffers than other areas of the watershed. Strahler (1964) proposed a method that can use to assign orders (Fig. 5).

In this method, the most upstream segments, or exterior links, are always assigned an order of one. Stream order increases when streams of the same order 
intersect. Therefore, the intersection of two first order links will create a second order link and the intersection of two second order links will create a third order link. The intersection of two links of different orders, however, will not result in an increase in order. For example, the intersection of a first order and second order link will not create a third order link, but will retain the order of the highest ordered link. The Strahler method is the most common stream ordering method, because this method only increases in order at intersections of the same order, it does not account for all links and can be sensitive to the addition or removal of links.

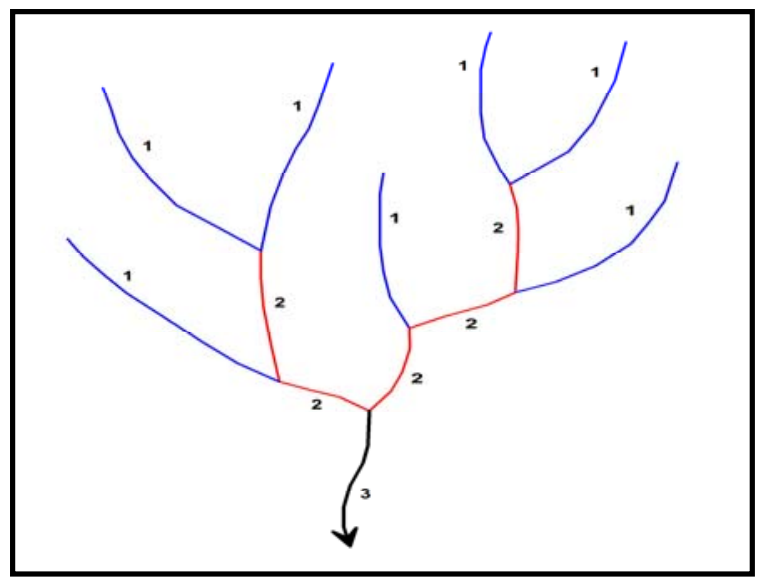

Fig. 5: Strahler method for order assigning.

The area of the study can be geomorphologically and hydrographically sub-divided into the following units: from the Red Sea coast westwards (Fig. 6):

1- The Red Sea coastal plain. 2- The Red Sea high mountains. 3- The coastal hilly area.

4- The morpho-tectonic depressions. 5- The drainage basins.

- The morpho-tectonic depressions: Two morpho-tectonic depressions are determined in the study area; these two depressions from north to south are Abu Ghusun depression and Bernice depression (Makram, 1993).

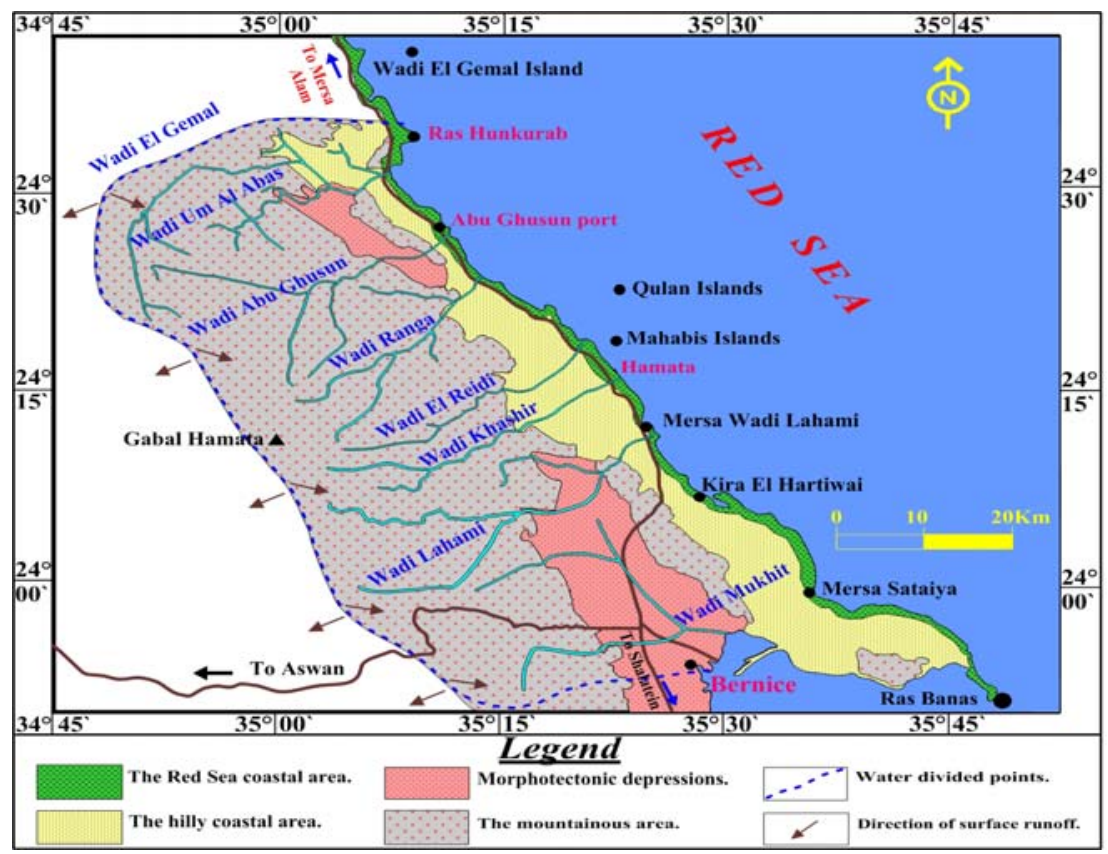

Fig. 6: The main geomorphologic units of the study area. 
The studied basins have the following characteristics:

a. The main direction of these basins is from S-W to N-E with many tributaries taking different directions.

b. All the basins cross different rock types.

c. Their drainage patterns are dendritic or semi-dendritic in the mountainous region, and trillic pattern in the sedimentary region.

d. The groundwater potentiality in these basins is affected to a large extent by the direction, density and length of the fractures and joints as well as the dykes and meanders of the drainage channels.

\section{Geomorphologic units:}

The significance of the quantitative part of geomorphology plays an essential role in estimating surface runoff. The significance of the morphometeric analyses on harvesting and groundwater exploration is applied at seven selected basins. The morphometeric characteristic analyses can best be expressed as:-

1. Linear scale variables. 2. Dimensionless numbers.

Linear scale variables include length of stream channel of a given order, drainage density, length to the center of the watershed, length of the longest water course and relief. Surface and cross sectional areas of the watershed are length products. Dimensionless products include stream orders, numbers, bifurcation ratios and channel gradients (slopes).

\section{RESULTS AND DISCUSSION}

\section{The drainage basins description:}

The studied basins can be briefly described according to their morphometric parameters in details, to determine the more or less risk areas and to manage the basins. A drainage basin, or catchments area as it is also called, is the part of the land surface that is drained by a single channel system. Most precipitation that falls on a drainage basin will eventually reach a main channel and flow to the sea.

A drainage divide on either side of which water will flow to separate basins, marks the perimeter of a catchments. The characteristics of such basins as area, length, peak discharge, valley length, circularity, gradient and other parameters determine how fast rainfall reaches a main river. Basin characteristics also help in determining the frequency, severity of flooding and the chance of groundwater recharge. Seven basins were selected to be studied in detail (Fig. 7), all of these basins cut through the high way between Abu Ghusun and Bernice.

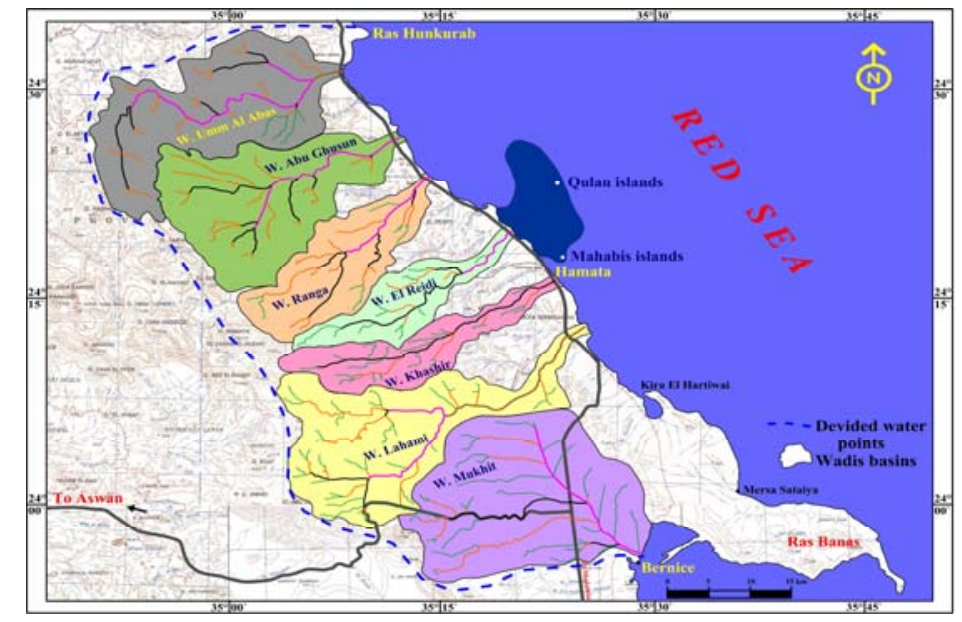

Fig. 7: The wadis and hydrographic basins of the study are 
The studied basins can be briefly described according to their morphometric parameters in details, to determine the more or less risk areas and to manage the basins as follow.

\section{Um Al Abas drainage basin:}

Um Al Abas basin lies between latitudes $24^{\circ} 19^{\prime} 50^{\prime \prime}-24^{\circ} 35^{\prime} \mathrm{N}$ and longitudes $34^{\circ} 49^{\prime}-35^{\circ} 10^{\prime} \mathrm{E}$ (Fig. 8). It is the northern end of study area $\left(450 \mathrm{~km}^{2}\right)$, nearly elongated and reflects the most favorable conditions for the short runoff distance. The drainage lines are dendritic to subdendritic pattern in the upper part and parallel to subparallel in the middle part and perimeter is $126 \mathrm{~km}$. The length of the main stream is the longest in the study area its reach to $52 \mathrm{~km}$ and it width varies from 200 to $600 \mathrm{~m}$.

The length of trunk attains $6 \mathrm{~km}$ and flows N-NE in the upper and lower parts to $\mathrm{N}-\mathrm{NW}$ in the middle part. Substantial tributaries of these channels are guided by faults. The basin reaches to the seven orders. The total number of tributaries reaches to 2404 ; it also characterized by intermediate drainage density, low relief ratio (25.19) and the total length of the segments attains $1516.5 \mathrm{~km}$. There are 3 water points (wells) in that basin and the basin has a funnel shape, nearly elongated.

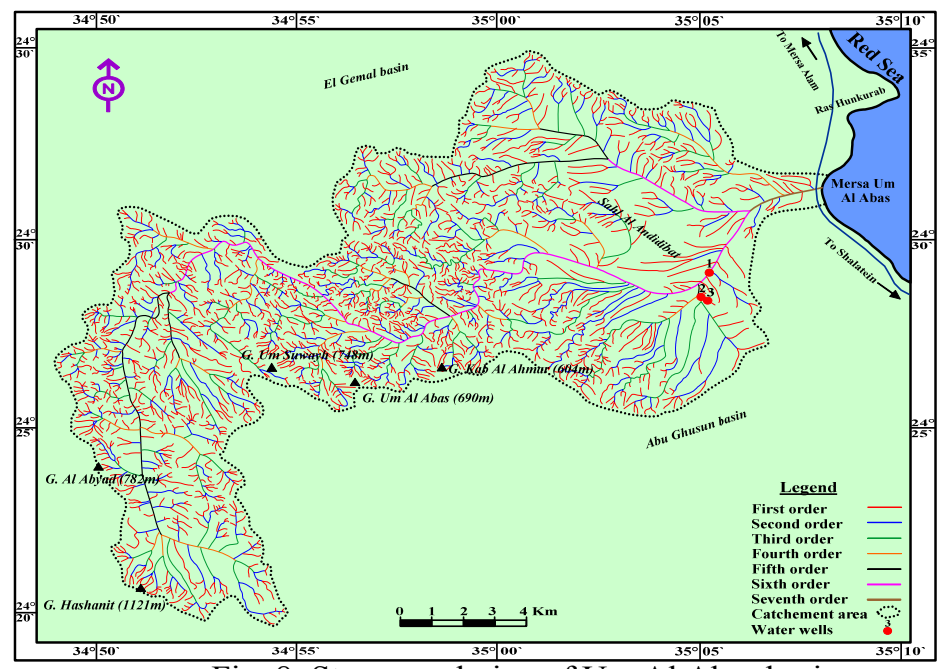

Fig. 8: Stream ordering of Um Al Abas basin.

\section{Abu Ghusun drainage Basin:}

Abu Ghusun basin lies between latitudes $24^{\circ} 15^{\prime}-24^{\circ} 28^{\prime} \mathrm{N}$ and longitudes $34^{\circ}$ $53^{`}-35^{\circ} 13^{`} \mathrm{E}$ (Fig. 9). Abu Ghusun basin drains through Abu Ghusun village, it has agriculture activities in the downstream part, mining activities in the middle part and upstream part as well granite quarries. It has a catchment's area is about $459 \mathrm{~km}^{2}$ and it has low slopes eastward. There are 14 water points (wells) in that basin, one well at the coast, 2 wells in coastal basement 6 wells in the morpho-tectonic plain), one well in the middle part of main channel, one well in Abu Ghalagah deep mine well (shaft), 3 wells in Rumayt tributary.

\section{Ranga drainage basin:}

Ranga basin lies between latitudes $24^{\circ} 11^{\prime} 10^{\prime \prime}-24^{\circ} 24^{\prime} 20^{\prime \prime} \mathrm{N}$ and longitudes $34^{\circ} 59^{\prime} 10^{\prime \prime}-35^{\circ} 15^{\prime} \mathrm{E}$ (Fig. 10). This basin is elongated in shape and the basin area reaches to $324 \mathrm{~km}^{2}$ and characterized by it's highly mountains ruggedness steepness of the upper part and the narrow lower part (outlet). The perimeter is $133 \mathrm{~km}$ and the length of the main channel is about $32 \mathrm{~km}$ and the length of trunk attains $15 \mathrm{~km}$ and flow SSW-NE, it width varies from $4 \mathrm{~km}$ to $300 \mathrm{~m}$. The basin reaches to the six 
orders, the total number of tributaries is 1333 , and their total lengths reach to 813.6 $\mathrm{km}$. There are 3 water points (wells) in that basin, one at the coast, 2 in the middle part of main stream (Daurat well) and the last one at the end of the basin (Hileifi well).

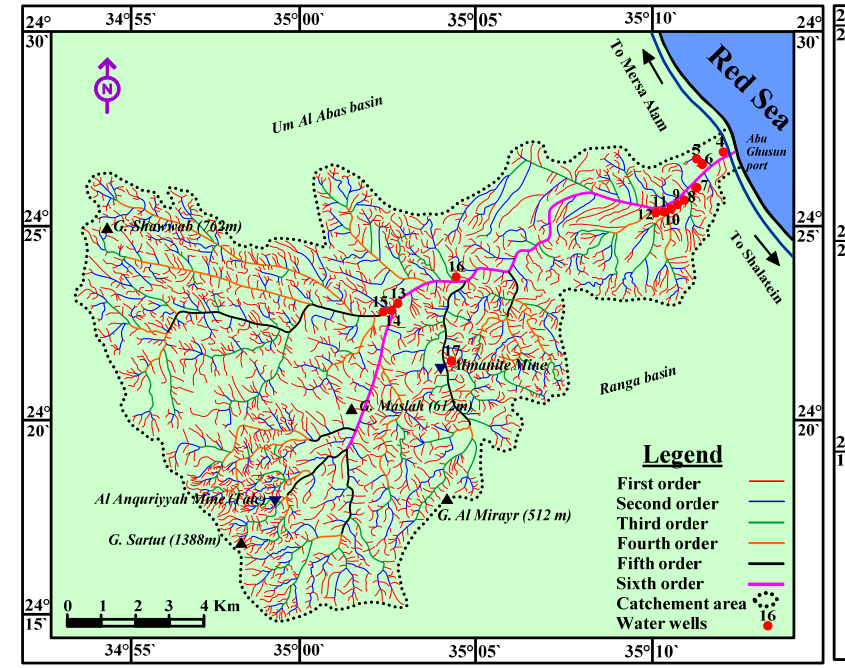

Fig. 9: Stream ordering in Abu Ghusun basin.

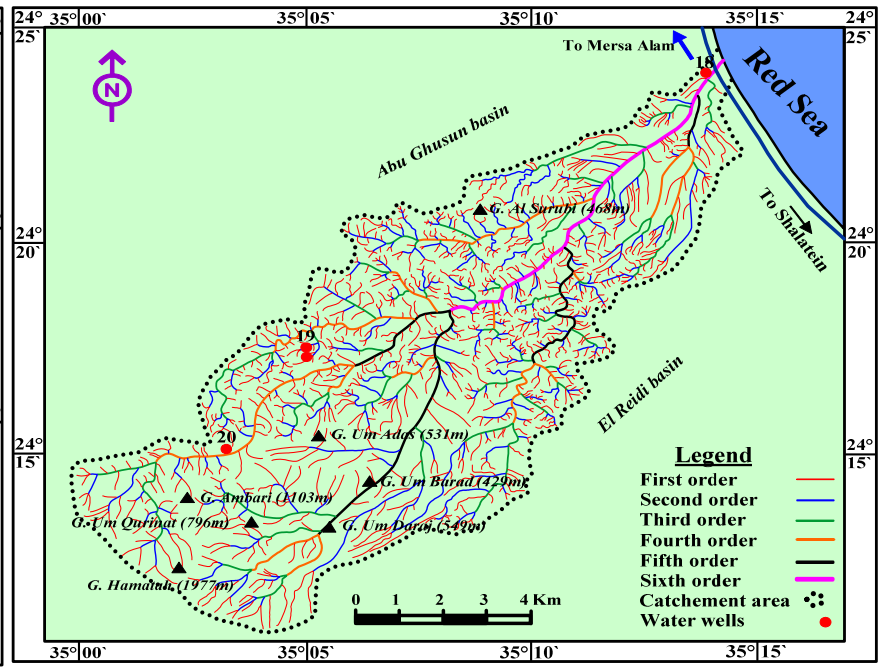

Fig. 10: Stream ordering in Ranga basin.

\section{El Reidi drainage basin:}

El Reidi basin lies between latitudes $24^{\circ} 11^{\prime} 30^{\prime \prime}-24^{\circ} 20^{\prime} \mathrm{N}$ and longitudes $35^{\circ}$ $05^{`}-35^{\circ} 20^{`} \mathrm{E}$ (Fig. 11). This basin is elongated in shape and characterized by low slope from upstream to downstream, also narrow at the upper part and the longer outlet parts, while low circularity at the middle part. This basin area reaches to 317 $\mathrm{km}^{2}$. It has mining activities in the middle parts as Talc Al Qulan and Talc El Reidi mines.

The drainage lines are dendritic to subdendritic pattern in the middle part and parallel to subparallel in the upper and lower parts, Perimeter is $136 \mathrm{~km}$ and the length of the main stream is $34 \mathrm{~km}$, it width varies reach to 400 to $200 \mathrm{~m}$ at the outlet. The length of trunk attains $9.5 \mathrm{~km}$ and flow SW-NE. The basin reaches to the six orders; the total number of tributaries reaches to 772, the total length of the tributaries attains $778.9 \mathrm{~km}$. There are 6 water points (wells) in that basin, one at the coast, 4 in the middle part of main channel (El Reidi and Al Haratreit wells) and the last one at the end of the basin (Hamata well).

\section{Khashir drainage basin:}

Khashir basin lies between latitudes $24^{\circ} 7^{\prime} 30^{\prime \prime}-24^{\circ} 16^{\prime} 50^{\prime \prime} \mathrm{N}$ and longitudes $35^{\circ} 03^{\prime}-35^{\circ} 24^{\prime} \mathrm{E}$ (Fig. 12). This basin area reaches to $303.5 \mathrm{~km}^{2}$; it's elongated in shape in the downstream and middle parts and semicircular at the upstream part, also it seem as syncline (arch shape) characterized by its ruggedness steepness of the upstream part and the narrow outlet part.

The drainage lines are dendritic to subdendritic pattern in the upper part and parallel to subparallel in the middle and lower parts. Perimeter is $88 \mathrm{~km}$ and the length of the main stream is $40.5 \mathrm{~km}$, it width varies reach to $500 \mathrm{~m}$ at the outlet. The length of trunk attains $35 \mathrm{~km}$ and flow SW-NE. The basin reaches to the five orders; the total number of tributaries reaches to 779 and the total length of the tributaries reaches to $963.6 \mathrm{~km}$. No water points were detected in that basin. 


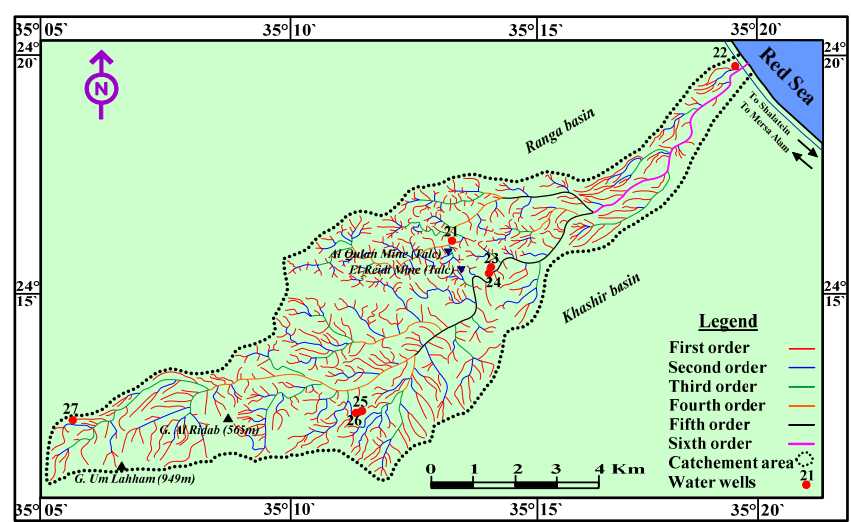

Fig. 11: Stream ordering in El Reidi basin.

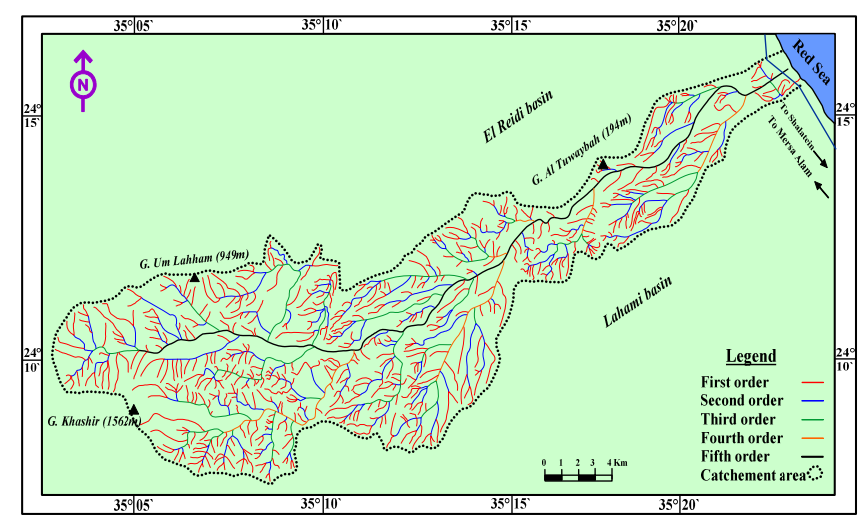

Fig. 12: Stream ordering in Khashir basin

\section{Lahami drainage basin:}

Lahami basin lies between latitudes $23^{\circ} 58^{\circ}-24^{\circ} 13^{\prime} \mathrm{N}$ and longitudes $35^{\circ} 02^{\prime}$ $50^{\prime \prime}-35^{\circ} 25^{\prime} 45^{\prime \prime} \mathrm{E}$ (Fig. 13). This basin area reaches to $497 \mathrm{~km}^{2}$ and its semicircular shape in the middle and upper parts except the lower part seem as elongated shape. Perimeter is $129 \mathrm{~km}$ and the length of the main stream is $48 \mathrm{~km}$ the length of main trunk attains $23.5 \mathrm{~km}$ and flow W-E in the middle part and again SE-NE the lower part of the basin.

This basin is characterized by its ruggedness steepness of the upstream part and narrow outlet part. The downstream part crossed by a short segment of the Red Sea coastal road, which is strongly vulnerable to flooding, this indicates that there is a high potential for flood hazards. The basin reaches to the 7 orders; the total number of tributaries reaches to 1511 and their total lengths reach to $1943.2 \mathrm{~km}$. It has mining activities in the upper parts as Humur Mine but it old unused, it has also it has local people settlements, in addition to safari trips and tourism activities. This Wadi has 7 water points (wells), one at the coast, 2 wells in the middle part in morphotectonic depressions and 4 wells in the upstream part of the basin.

\section{Mukhit drainage basin:}

Mukhit basin locates in the southern part of the study area between latitudes $23^{\circ} 53^{\prime} 50^{\prime \prime}-24^{\circ} 07^{\prime} \mathrm{N}$ and longitudes $35^{\circ} 11^{\prime} 50^{\prime \prime}-35^{\circ} 30^{\prime} 20^{\prime} \mathrm{E}$ (Fig. 14). This basin area reaches to $837.5 \mathrm{~km}^{2}$; it's circularity in shape, also characterized by its ruggedness steepness of the upstream part and it has the biggest width of outlet part reach to $4-5 \mathrm{~km}$, with very low slope. This basin is characterized by low drainage density and reaches to the six orders. The drainage lines are parallel to subparallel in the eastern half of basin dendritic to subdendritic pattern in the western half of the basin, the total number of tributaries reaches to 1079, the total length of the tributaries attains $2091.7 \mathrm{~km}$. Perimeter is $125 \mathrm{~km}$ and the length of the main stream is $39 \mathrm{~km}$. The length of trunk attains $24 \mathrm{~km}$ and flow N-S in the upper and middle parts and again NW-SE in the lower part of the basin.

The eastern and western mountains chains of Precambrian rocks are composed of old granite, diorite and metadiorite rocks. There are 3 water points (wells) in that basin, one in the Upper part of Abu Qurayyah tributary, one in the middle part of basin on side of Bernice- Aswan road (Al Hafiri well) and the last one in the southern part in the basin and the study area (Taww well). 


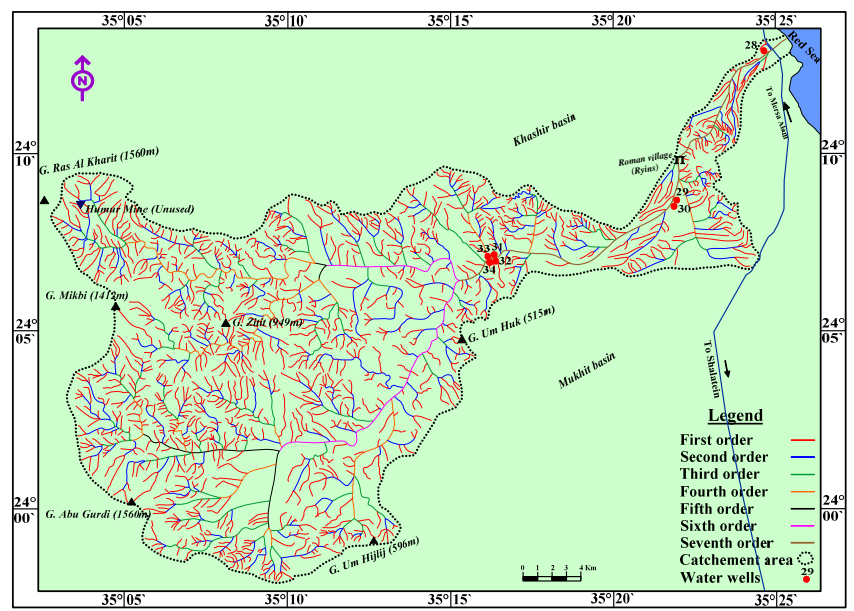

Fig. 13: Stream ordering in Lahami basin.

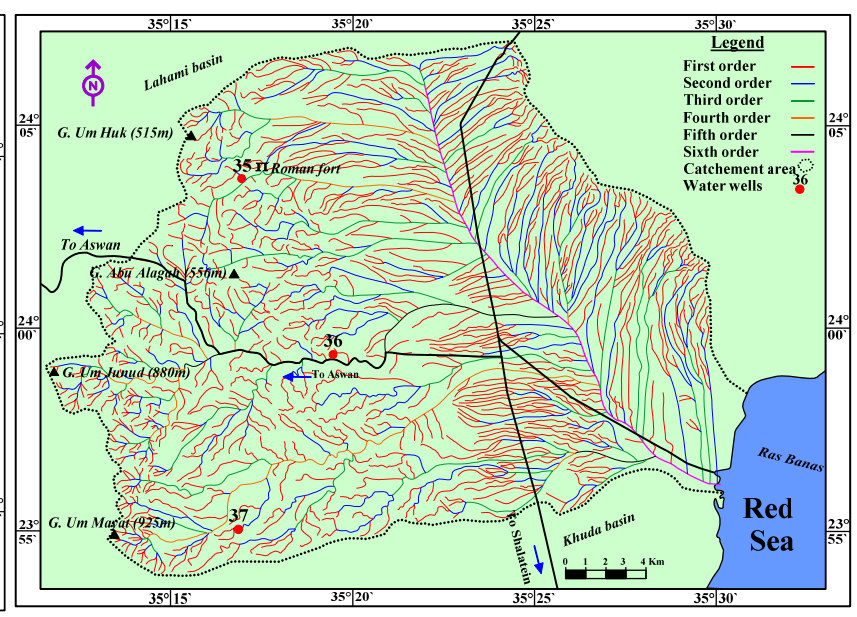

Fig. 14: Stream ordering in Mukhit basin.

Geomorphologic analyses:

The linear characteristics of the drainage basins:

The linear characteristics of the study basins can be discussed as follow:

\section{Stream ordering (u)}

According to Horton (1945), the stream ordering has been determined after Strahler method (1952), the unbranched fingertip tributary is designed as of $1^{\text {st }}$ order; tributary of $2^{\text {nd }}$ order receives branches of tributaries of $1^{\text {st }}$ order, a stream of $3^{\text {rd }}$ order receives one or more tributaries of $2^{\text {nd }}$ order and also perhaps receive $1^{\text {st }}$ order branches. A stream of $4^{\text {th }}$ order receives branches of $3^{\text {rd }}$ order and also of lower orders and so on. Each order has a different color than the other ones. In the studied area the trunk channel for the studied basins has stream order varies from $5^{\text {th }}$ to $7^{\text {th }}$ order. The trunk channel of every basins drains in the Red Sea (Table 3).

\section{Bifurcation ratio $(\mathbf{R b})$}

Bifurcation ratio $(\mathrm{Rb})$ defined as the ratio between the number of stream order $(\mathrm{Nu})$ to the number of the next order $(\mathrm{Nu}+1)\left(\mathrm{Rb}=\mathrm{N}_{\mathrm{u}} / \mathrm{N}_{\mathrm{u}+1}\right)$. The high values of $\mathrm{Rb}$ express elongated basins. The studied basins have $\mathrm{Rb}$ values ranges between 3.45 as in Lahami basin to 5.01 as in Khashir basin. The studied basins have Rb values greater than 3 reflecting high mountainous dissected areas (Horton 1945) (Table 3).

\section{Stream numbers $(\mathrm{Nu})$ and stream lengths $(\mathrm{Cu})$}

The stream numbers and lengths of each order for all basins and tributaries were measured. Abu Ghusun basin has the greatest number of streams (2544) and El Reidi basin has the smallest number of streams 772 (Table 1), while Mukhit basin has the greatest total length of streams attains $2091.7 \mathrm{~km}$ El Reidi basin has the smallest total length of streams attains $778.9 \mathrm{~km}$ (Figs. 15, 16 \& 17).

Valley length (VL) and basin length (LB)

The stream length (VL) depends on the shape of the basin. The basin length (LB) is the line dividing the basin into two halves from the mouth to the source (semi street); it ranges between $27 \mathrm{~km}$ as in El Reidi basin to $44.5 \mathrm{~km}$ as in Um Al Abas basin (Table $2 \& 3$ ).

\section{Sinuosity ratio (Si)}

The sinuosity ( $\mathrm{Si}$ ) is defined by the length of the wadi path (VL) to the shortest distance between mouth and the source of stream (semi street) (LB) i.e $\mathrm{Si}=\mathrm{VL} / \mathrm{LB}$ (Gregory and Willing, 1973). The studied basins have sinuosity values ranging between 1.10 as in Ranga basin to 1.67 as in Abu Ghusun basin. 


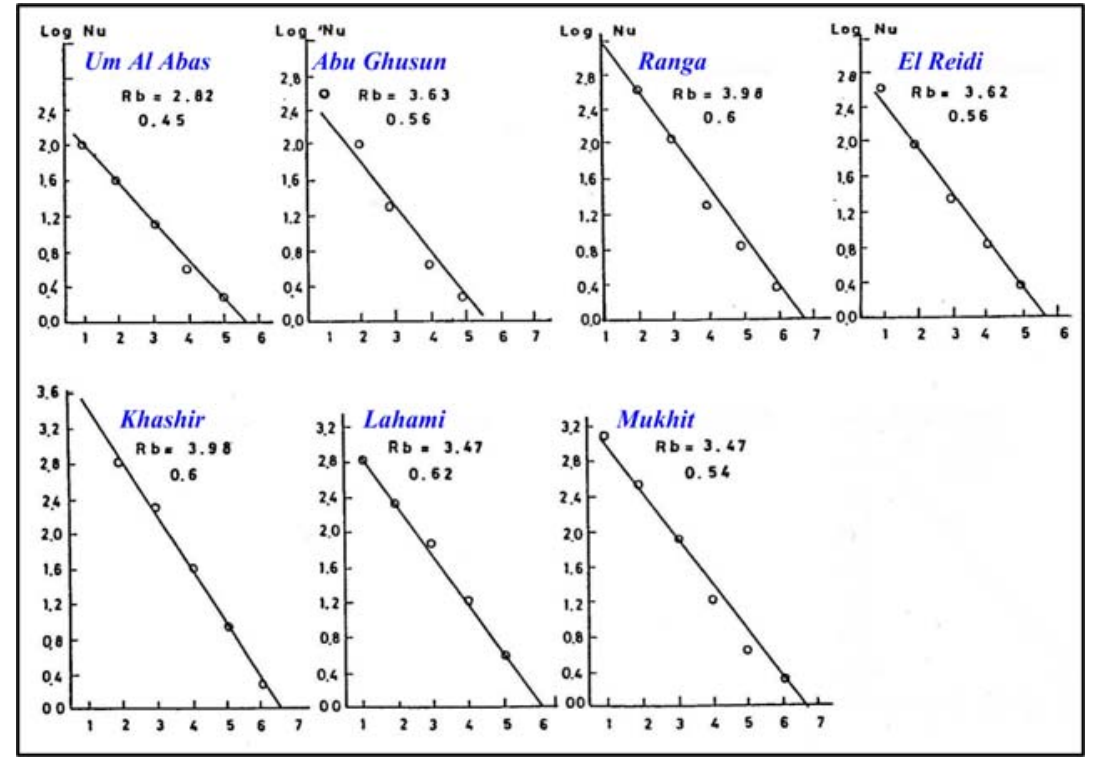

Fig. 15: Relationship between stream order and stream number (Estimation of the bifurcation ratio $\mathrm{Rb}$.)

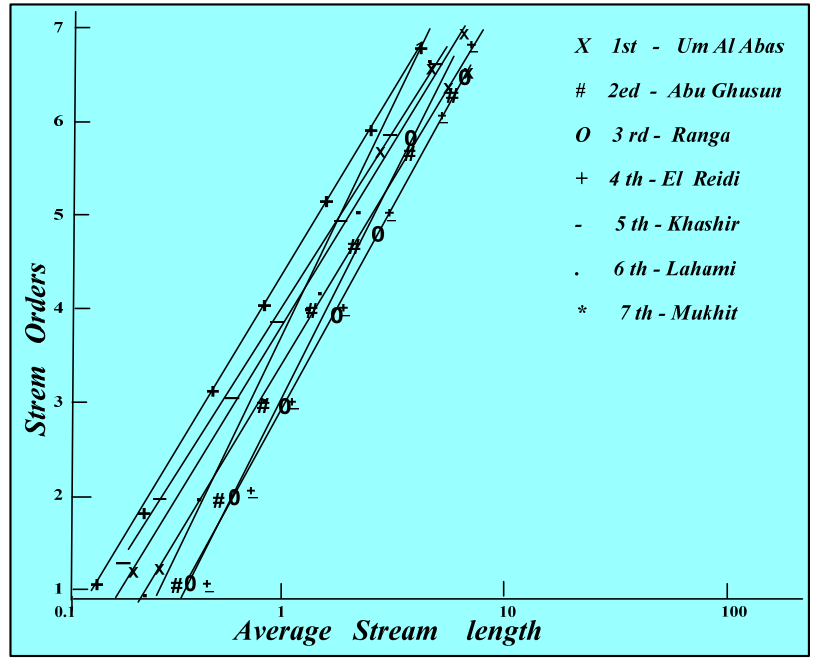

Fig. 16: Relationship between stream order and stream number (using Strahler's system of ordering).

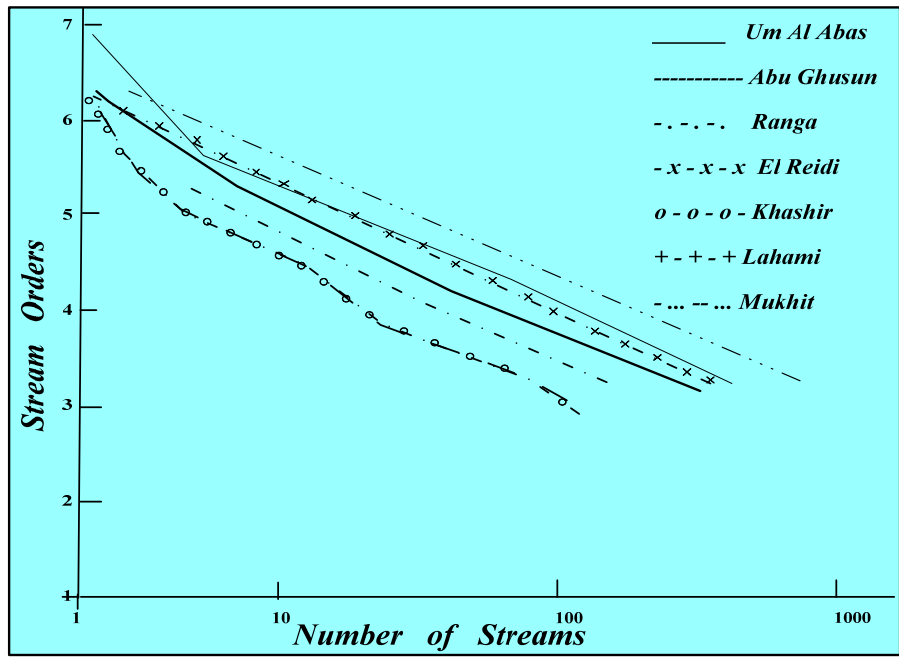

Fig. 17: Relationship between stream orders and average stream length.

\section{Basin perimeter $(\mathrm{P})$}

The perimeter $(\mathrm{P})$ is the length of the line that outlined the basin area. The stream perimeter is directly proportional to the area of the basin and the curvature of the basin margins. The studied basins range in perimeter from $88 \mathrm{~km}$ as in Khashir basin to $136 \mathrm{~km}$ as in El Reidi basin. 
Table 1: Cumulative number and cumulative $\%$ of the analyzed streams.

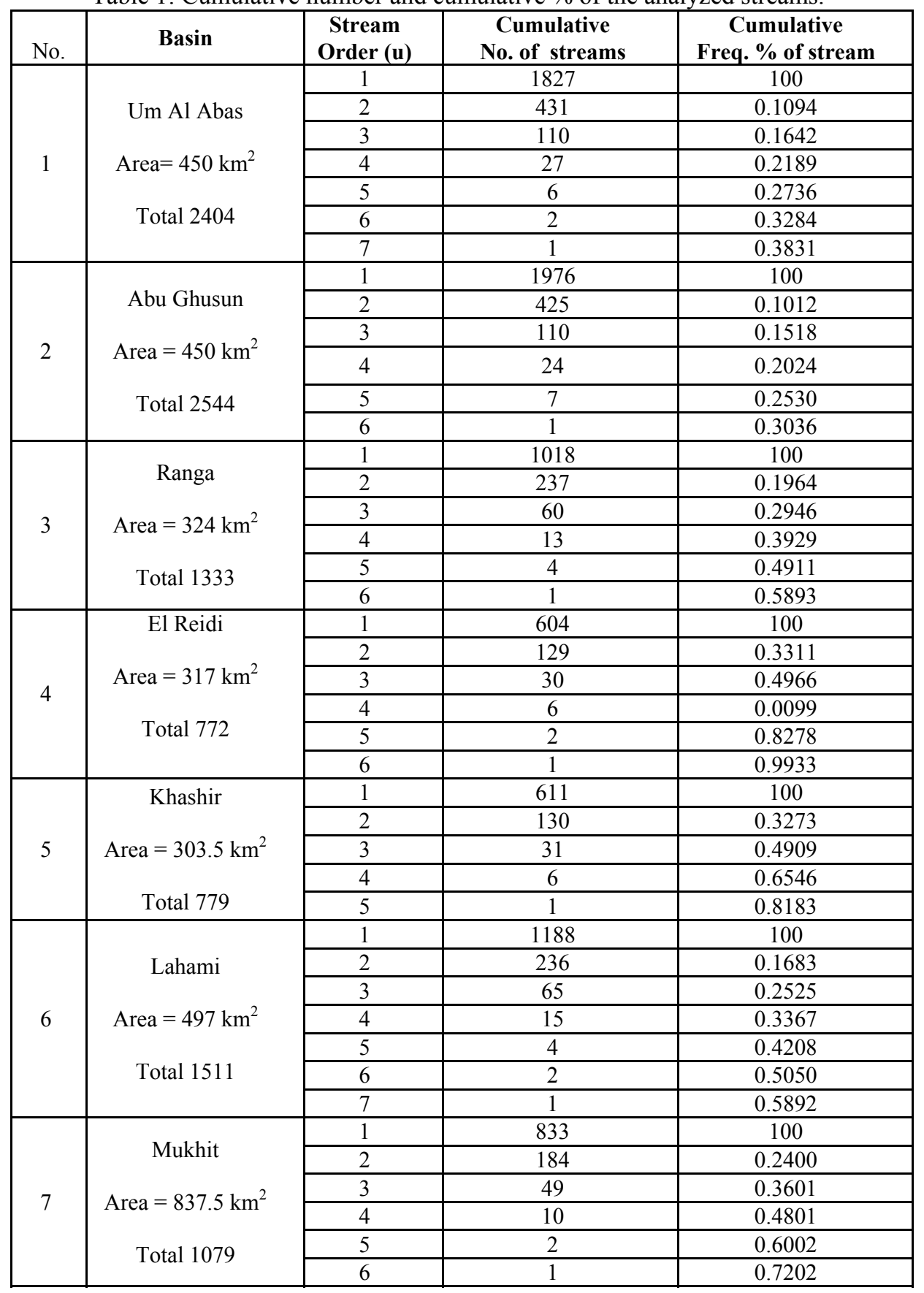

Table 2: Relief characteristics of the studied basins.

\begin{tabular}{|l|l|l|l|l|l|}
\hline No. & Drainage Basin & $\begin{array}{c}\text { Relief } \\
\text { Difference }\end{array}$ & $\begin{array}{c}\text { Basin } \\
\text { length }\end{array}$ & $\begin{array}{c}\text { Relief } \\
\text { Ratio }\end{array}$ & $\begin{array}{c}\text { Elongation } \\
\text { Ratio }\end{array}$ \\
\hline 1 & Umm Al Abas & 1.121 & 52 & 25.19 & 0.53 \\
\hline 2 & Abu Ghusun & 1.388 & 51 & 45.51 & 0.79 \\
\hline 3 & Ranga & 1.751 & 32 & 60.38 & 0.69 \\
\hline 4 & El Reidi & 1.562 & 34 & 35.14 & 0.74 \\
\hline 5 & Khashir & 0.979 & 40.5 & 45.94 & 0.57 \\
\hline 6 & Lahami & 1.56 & 48 & 37.14 & 0.59 \\
\hline 7 & Mukhit & 0.925 & 39 & 26.42 & 0.93 \\
\hline
\end{tabular}

\section{The areal characteristics of the drainage basins:}

The areal characteristics of the basins are related to the flow and sediment yield; this can be discussed as follow: 


\section{Basin area, $\mathrm{A}\left(\mathrm{km}^{2}\right)$ :}

The drainage basin area is the size of the contributing drainage area expressed in square kilometers or hectares. The studied basins area ranges from $303.5 \mathrm{~km}^{2}$ (Khashir basin) to $837.5 \mathrm{~km}^{2}$ (Mukhit basin). El-Etr and Ashmawy (1994) classified basins into three main types, there are large basins, those which are characterized by an area of more than $200 \mathrm{~km}^{2}$, the medium basin ranges from 200 to $60 \mathrm{~km}^{2}$ and the small basin is less than $60 \mathrm{~km}^{2}$ in area. According to the former classification, all of the study basins considered as large basins (Table 3).

\section{Basin width (WB):}

Average width of the basin is determined by dividing the area by the basin length (LB). WB = A / LB. In the study area Mukhit basin registered the greatest value of the basin width as it recorded 23.92, while Khashir basin recorded the lowest value of the basin width as it recorded 8.92.

\section{Drainage density (D):}

Drainage density is the total length of all the streams in the basin to the area of the whole basin $\left(\mathrm{D}=\sum \mathrm{L}_{\mathrm{u}}\right.$ (total length of streams $\left.\mathrm{km}\right) / \mathrm{A}\left(\right.$ basin area $\left.\mathrm{km}^{2}\right)$. The drainage density is usually higher on clayey rocks of low permeability than on sand or chalk with higher infiltration capacities. High values of drainage density indicate regions of large numbers and lengths of contributing tributaries, impermeable surface or rugged mountains relief (Strahler 1964). Basins with low drainage density numbers indicate regions of highly permeable or highly resistant subsoil material under dense vegetation. While basins with high drainage density numbers indicate appreciable local amount of rainfall, but on the other hand high flood peaks and low contribution to groundwater (Orbson 1970). Lahami basin registered the greatest value of the drainage density as it recorded 3.90, while Mukhit basin recorded the lowest value of the drainage density as it recorded 2.49 (Table 3 )

\section{Length of overland flow (Lo):}

It is defined as the distance that water flows over the ground surface before it becomes concentrated in drainage network (Horton, 1945). It is expressed by the reciprocal of twice the drainage density i.e. Lo $=1 / 2 \mathrm{D}$. It attains the smallest value 1.24 in Mukhit basin and attains 1.95 in Lahami basin which indicates that the water is faster to concentrate in the drainage channel.

\section{Drainage frequency $(F)$ :}

The drainage frequency is defined as the number of drainage segments per unit areas (Horton, 1945) i.e. $\mathrm{F}=\Sigma \mathrm{Nu}$ (total number) / A (basin area). It measures the texture of the drainage net. If the value of $(F)$ is high, this gives an indicator for the large number of tributaries and also the chance for collecting water to the main wadi. Accordingly the flood chance increase and vice versa. Frequency distribution in the studied basins ranges from 1.28 as in Mukhit basin to 5.54 as in Abu Ghusun basin.

Texture ratio $(\mathbf{R t})$ :

The texture ratio (Rt) is defined as the ratio of the total number of the basin's segments to its perimeter $\left(\mathrm{Rt}=\sum \mathrm{Nu} / \mathrm{P}\right)$. It was classified by Smith (1958) into coarse textured $\left(\mathrm{Rt}<6.4 \mathrm{~km}^{-1}\right)$, intermediate textured $\left(\mathrm{Rt}=6.4-16 \mathrm{~km}^{-1}\right)$ and fine textured (Rt $\left.>16 \mathrm{~km}^{-1}\right)$. El Reidi has a coarse texture (5.66), Abu Ghusun and Um El Abas basins have fine textures and the other studied basins have intermediate textures. This gives an indication that most of the studied basins are in advanced stage. 
Table 3: Morphometric parameters of the selected hydrographic basins in the study area.

\begin{tabular}{|c|c|c|c|c|c|c|c|}
\hline Parameters & $\begin{array}{c}\text { Um Al } \\
\text { Abas }\end{array}$ & $\begin{array}{c}\text { Abu } \\
\text { Ghusun }\end{array}$ & Ranga & El Reidi & $\begin{array}{c}\text { Khas } \\
\text { hir }\end{array}$ & $\begin{array}{c}\text { Laha } \\
\text { mi }\end{array}$ & Mukhit \\
\hline $\begin{array}{ll}\mathbf{U} & \text { Stream ordering }\end{array}$ & 7 & 6 & 6 & 6 & 5 & 7 & 6 \\
\hline $\begin{array}{ll}\mathbf{N u} & \text { Sum of stream numbers } \\
\end{array}$ & 2404 & 2544 & 1333 & 772 & 779 & 1511 & 1079 \\
\hline \begin{tabular}{|l|l}
$\mathbf{L u}$ & Sum of stream lengths $(\mathrm{km})$
\end{tabular} & 1516.5 & 1514.9 & 813.6 & 778.9 & 963.6 & 1943.2 & 2091.7 \\
\hline Basin Area $\left(\mathrm{km}^{2}\right)$ & 450 & 459 & 324 & 317 & 303.5 & 497 & 837.5 \\
\hline WB Basin width & 10.11 & 15.04 & 11.17 & 11.74 & 8.92 & 11.83 & 23.92 \\
\hline Basin Perimeter $(\mathrm{km})$ & 126 & 109 & 133 & 136 & 88 & 129 & 125 \\
\hline VL Valley length $(\mathrm{km})$ & 52 & 51 & 32 & 34 & 40.5 & 48 & 39 \\
\hline LB $\quad$ Basin length $(\mathrm{km})$ & 44.5 & 30.5 & 29 & 27 & 34 & 42 & 35 \\
\hline Sinuosity ratio & 1.16 & 1.67 & 1.10 & 1.37 & 1.19 & 1.14 & 1.11 \\
\hline $\begin{array}{ll}\mathbf{R b} & \text { Bifurcation ratio }\end{array}$ & 3.62 & 4.6 & 4.02 & 3.89 & 5.01 & 3.45 & 4.036 \\
\hline D $\quad$ Drainage density & 3.37 & 3.30 & 2.51 & 2.80 & 3.17 & 3.90 & 2.49 \\
\hline Lo Length of overland flow & 1.68 & 1.65 & 1.25 & 1.40 & 1.58 & 1.95 & 1.24 \\
\hline F $\quad$ Drainage frequency & 5.34 & 5.54 & 4.11 & 2.43 & 2.56 & 3.04 & 1.28 \\
\hline $\begin{array}{ll}\text { Rt } & \text { Texture ratio } \\
\end{array}$ & 19.07 & 23.33 & 10.02 & 5.66 & 8.85 & 11.71 & 8.63 \\
\hline $\begin{array}{ll}\text { Rc } & \text { Circularity ratio }\end{array}$ & 3.5 & 0.48 & 0.230 & 0.215 & 0.49 & 0.37 & 0.67 \\
\hline Re $\quad$ Shape index & 0.53 & 0.79 & 0.69 & 0.74 & 0.57 & 0.59 & 0.93 \\
\hline Ish $\quad$ Shape index & 0.28 & 0.62 & 0.48 & 0.55 & 0.33 & 0.35 & 0.86 \\
\hline $\begin{array}{ll}\mathbf{S} & \text { Inverse shape form } \\
\end{array}$ & 4.40 & 2.026 & 2.59 & 2.29 & 3.80 & 2.54 & 1.46 \\
\hline Rr $\quad$ Relief ratio & 25.19 & 45.51 & 60.38 & 35.14 & 45.94 & 37.14 & 26.42 \\
\hline SI $\quad$ Slope index & 13.97 & 6.14 & 17.83 & 12.74 & 15.70 & 11.19 & 6.94 \\
\hline Rn Ruggedness number & 3777.7 & 4580.4 & 4395.01 & 2657.2 & 4951.5 & 6084 & 2303.2 \\
\hline $\mathbf{R} \quad$ Relief $=$ Internal relief $(\mathrm{km})$ & 1121 & 1388 & 1751 & 949 & 1562 & 1560 & 925 \\
\hline
\end{tabular}

Basin shape Rc, Re \& Ish:

The parameter has been expressed by three ways, circularity ratio (Rc) where $\mathrm{Rc}=4 л \mathrm{~A} / \mathrm{P}^{2}$ (Miller, 1953), elongation ratio (Re) (Schumm, 1956) Table 2; where $\mathrm{Re}=2 \times\left(\mathrm{A} /\right.$ л) ${ }^{0.5} / \mathrm{LB}$ and shape index (Ish) (Hagget, 1956); Ish $=1.27 \mathrm{~A} / \mathrm{LB}^{2}$ where $\mathrm{A}$ is the area of the basin and LB is the maximum length of the basin (semi street). The basin shape index (Ish) has its influence on the hydrologic characteristics such as flow and sediment load yield. The time for concentration of flow to the main channel is less in circular basin than in elongated one.

The studied basins attain circularity ratio $(\mathrm{Rc})$ value between 0.215 as in El Reidi basin to 0.67 as in Mukhit basin, this gives an indication that Mukhit basin is more circular than the other basins. On the other hand, the shape index values range between 0.28 as in Um Al Abas basin to 0.86 as in Mukhit basin.

Inverse shape form (S):

The inverse shape form $(\mathrm{S})$ is defined as the relation between the square of the basin length (LB) and the watershed area (A) as: $\mathrm{S}=\mathrm{LB}^{2} / \mathrm{A}$

Where; $\mathrm{S}=$ =inverse shape form (dimensionless), $\mathrm{LB}=$ basin length (semi street $\mathrm{km}$ ) and $\mathrm{A}=$ the catchments area $\left(\mathrm{km}^{2}\right)$. It ranges between 1.46 (Mukhit basin) and 4.40 (Um Al Abas basin). It reflects high ability in Um Al Abas basin to form flash flooding.

\section{The relief characteristics of the drainage basins:}

The relief characteristics of a drainage basin is expressed by three parameters; relief ratio, slope index and ruggedness number:

Relief ratio (Rr) has been introduced by Schumm (1956) and described by the equation $\mathrm{Rr}=\mathrm{R} / \mathrm{LB}$, where $\mathrm{R}$ is the difference in elevation between head and mouth of the basin and (LB) is the maximum length of the basin (semi street). It ranges between 60.38 (Ranga basin) to 25.19 (Um Al Abas basin). The relief ratio is an expression of drainage basin relief in a two dimensional form (elevation and 
distance). The slope of any basin is expressed by the elongation ratio, between the diameter of a circular with the same area and the maximum length of the basin as measured for the relief ratio $(\mathrm{Rr})$ is plotted against drainage density (D), also against the elongation ratio on a log- log paper (Table 2) (Figs. $18 \& 19$ respectively).

Ruggedness number (Rn) is an expression introduced by Melton (1957). It is expressed by the equation $\mathrm{Rn}=\mathrm{D} \times \mathrm{R}$ It ranges between 2.62 (Mukhit basin) to 7.18 (Khashir basin), which reflects that El Reidi basin has the greatest runoff and sediment load yield (Table 3).

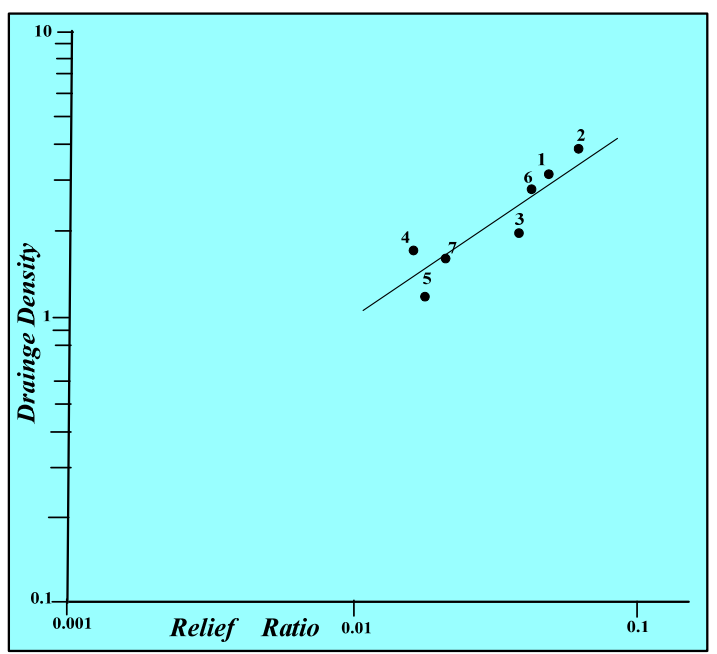

Fig (18): Relationship between drainage density and relief ratio using Strahler`s system of ordering.

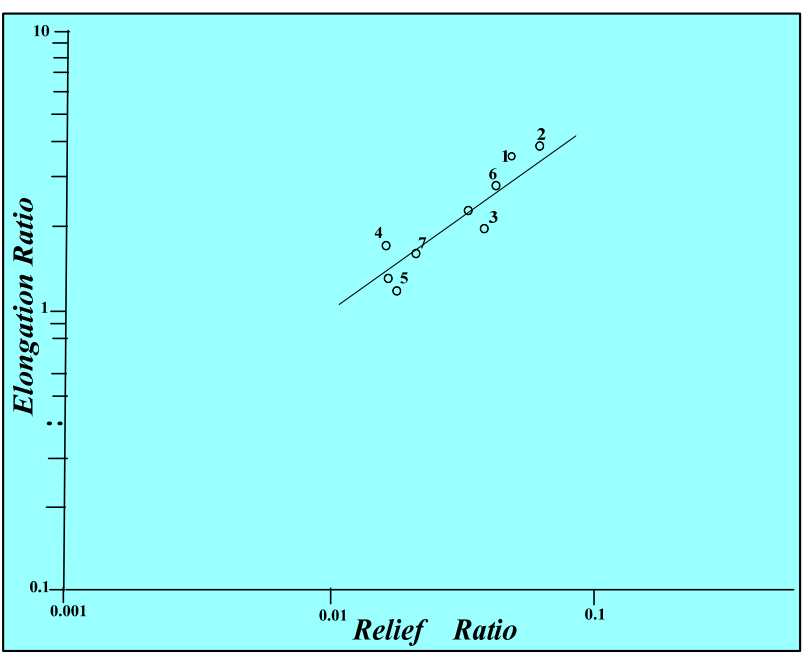

Fig (19): Relationship between elongation ratio and relief ratio.

\section{Hydrogeologic setting:}

The hydrogeologic setting in the study area was discussed under the topics, general hydrogeologic setting, hydrogeologic units, effect of structure on groundwater movement and Palaeo-hydrogeologic Cycles. General hydrogeologic setting the investigated area is represented as a part of the regional hydrogeologic basins (Red Sea basin), bounded from the east by the Red Sea coast, and from the west by the high mountainous range of basement rocks. The regional catchment area lies at the mountainous range of the basement rocks, divides the water flows towards the Red Sea coast at the east and to the Nile Valley at the west. The water supplies in the area of study are found in the drainage basins dissecting the Red Sea mountainous region.

The vertical hydrgeological classification of the study area is based upon age assignment, lithological and hydrogeologic characters of the rock units. The area of study represents itself as a part of the Red Sea regional hydrogeological basin of first order while the studied basins are classified to be hydrogeological basins of second order. The groundwater flows are regionally directed to the NE towards the Red Sea, where the area of discharge is located at the coastal plain. Two main hydrogeologic types of aquifers are found to be arranged vertically and passed upon age assignment, lithological and hydrogeological characters of the rock units. The main characters of the hydrogeological units from down upwards are given as:

The aquitard fractured Precambrian basement water bearing rocks, according to the lithology of rock types these rocks are subdivided into three subdivisions as:

A- The aquitard fractured Metamorphic Rocks (5 wells)

B- The aquitard fractured plutonic rocks (15 wells)

C- The aquitard fractured Hammamat rocks (2 wells) 


\section{The sedimentary water bearing aquifers:}

1 - The Miocene sandstone water-bearing aquifer ( 5 wells)

2- The Costal Miocene coral reef aquifer (4 wells)

3- The Quaternary and Pleistocene deposits (6 wells).

The Aquitard Fractured Precambrian Basement Rocks:-

The Aquitard Fractured Metamorphic Rocks:

These rocks include the metasediments, the metavolcanics and serpentenites and related rocks. They exist at different localities namely; Wadis Abu Ghusun, Qalan and Makhit. Five water points are detected in this aquitard. The groundwater reservoirs exist in joints, faults and fractures. The quantity of water is rottenly limited, but services for local populations. This aquitard receives recharges from direct precipitation and occasional tolerant sudden floods, which cause dilution to the groundwater. The water salinities range from brackish to saline (T.D.S. ranges from 2652 to $11782 \mathrm{ppm}$ ), and the depth to water varies from 1.52 to $6.5 \mathrm{~m}$.

\section{The Aquitard Fractured Plutonic Rocks:-}

These are composed of granite, granodiorite and related rocks. They exist in all basins in the area of study (in 15 water wells). They attain groundwater accumulations in the highly weathered and fractured zones of these rocks. The dykes act as water barriers in most of these localities. The depth to water ranges from 3.8 to $22.3 \mathrm{~m}$. and the salinity varies from $1300 \mathrm{ppm}$ to $5860 \mathrm{ppm}$.

\section{The Aquitard Fractured Hammamat Rocks:-}

These are un-metamorphosed sediments composed of fine or coarse grained breccia and conglomerates derived from Dokhan volcanics. They are detected as water bearing at two wells in Abu Ghusun basin. The depth to water ranges from 22.6 to $31.9 \mathrm{~m}$, from the ground surface, while the TDS ranges from 11438 to 13872 ppm).

\section{The Sedimentary Aquifers:-}

The Miocene Sandstone Aquifer:

This aquifer is formed of conglomerates, sandstones and shales with high porosity and permeability. It was detected as water bearing in 5 wells at Um Al Abas and Lahami basins at depths ranges from 18 to $48.5 \mathrm{~m}$. Its salinity varies from 2904 to $8583 \mathrm{ppm}$.

\section{The Coastal Miocene Coral Reefs Aquifer:}

This aquifer is formed of conglomerates, sandstone and coral limestone. Its porosity and permeability are considerable. Its thickness ranges between 224 and 234 $\mathrm{m}$. The fractured coral reefs are developed to constitute an aquifer at Abu Ghusun, Ranga, El Reidi and Lahami basins at the shore line. The depth to water varies from 3.0 to $5.3 \mathrm{~m}$ and the water salinity ranges from 6360 to $12673 \mathrm{ppm}$.

\section{The Quaternary and Pleistocene Deposits:}

These deposits occur as terraces in the fans of the wades at the Red Sea coastal region and rest on the older sedimentary rocks. They are formed of detritus sands, pebbles and rare boulders. They are developed as aquifers in Abu Ghusun basin. The groundwater occurs mainly under free water table condition. The depth to water generally ranges from 5.5 to $13 \mathrm{~m}$. The groundwater produced from the coastal alluvial deposits is brackish to highly saline (T.D.S. $2989-9879$ ppm).

Fluctuation in water salinities is noticed to exist during seasons and attributed to direct precipitation and occasional torrents causing dilution to the accumulated groundwater within fissures. The effect of structure on groundwater movement the structural elements are important factors controlling the groundwater occurrence, quality and quantity. The groundwater resources in the study area originate mainly 
from occasional rainfall. Partially this water infiltrates through the friable loose sediments and accumulates in the sediments or in the fractured Precambrian rocks. Most of wells were drilled closed to dykes, this give an indication that there is an important relation between the structure and the groundwater movement like Rumayt wells.

Managing the hydrographic basins is the best way to avoid risk along the coastal area. The appropriate flood control approach is to open as much space as possible to accommodate stream overflow, the other important thing in the open approach is to ensure free passage of water to the sea. A flood water management system may be established, this can be accomplished through building dams by accumulating boulders of weathering products without cementation, these dams have to be constructed at narrow parts of gentle slope courses of the chosen small basins. The study proposed a protection dam sites for the investigated basins (Fig. 20).

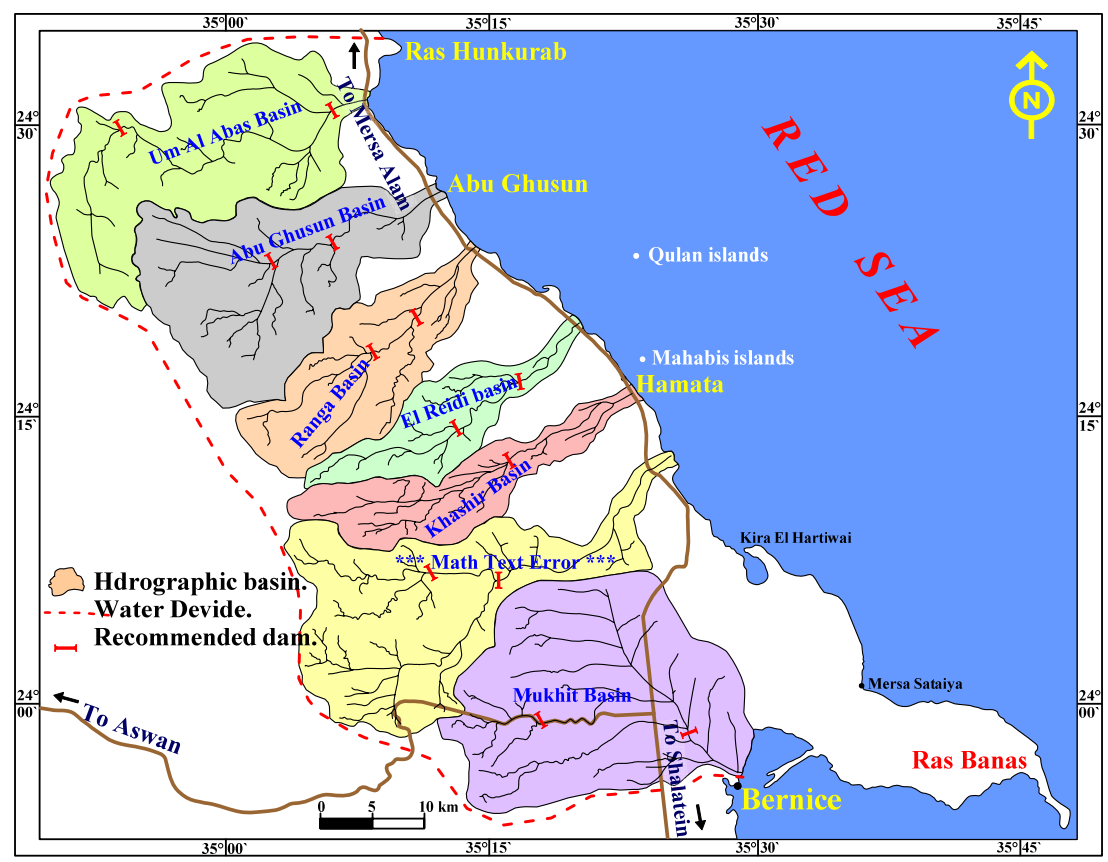

Fig. 20: Proposed sites for construction of some dams along the study area.

The marine period of the first paleo-hydrogeological cycle began by sea transgression at the beginning of Upper Cretaceous and continued till the Middle Eocene, where the continental period of the same first cycle began from the end of Middle Eocene and continued till nowadays in the belt of these hydrogeological basins. The continental period of this first paleo-hydrogeological cycle ended at the coastal plain of the Red Sea by the sea transgression at the end of Lower Miocene where the marine period of the second paleo-hydrogeological cycle began and continued till the end of Pleistocene time. The continental period of the same second paleo-hydrogeological cycle began and continued till nowadays along the Red Sea coast at the east.

The total number of stream tributaries included in the present study amount 10422. The obtained results are in general in agreement with Horton's laws. So, Khashir basin shows a different slope than the others. The average (mean) of bifurcation ratio of the seven basins is 4.089 , which close to the 3.5 for many streams in Egypt and U.S (Table 4). Thus, the morphometric studies of drainage basins suggest a bifurcation ratio of 3.79 is compared almost the same at some parts of Egypt. That small bifurcation ratio indicates dangerous floods. The drainage basins 
area in the region under study ranges from small (303.5 $\mathrm{km}^{2}$ in Khashir basin), to big $\left(837.5 \mathrm{~km}^{2}\right.$ in Mukhit basin), with average about $570.5 \mathrm{~km}^{2}$.

The relationship between basin area and stream length was determined. The value of 0.6 of the study area suggested a tendency towards narrow and elongate basins. Generally has noted this tendency in arid basins. Elongation ratio has been also a function of the slope and relief basins tend to become elongate with the strong relief and steep slope. The elongated basins (e.g. Khashir \& El Reidi basins) indicate a strong relief and steep slope of that part of the Red Sea Mountains.

Table 4: Summary of Bifurcation Ratio and Drainage Density of Ex-studied basin (for comparison)

\begin{tabular}{|c|l|c|c|l|}
\hline $\begin{array}{c}\text { No } \\
.\end{array}$ & \multicolumn{1}{|c|}{ Basin } & $\begin{array}{c}\text { Bifurcation } \\
\text { Ratio }\end{array}$ & $\begin{array}{c}\text { Drainage } \\
\text { Density }\end{array}$ & \multicolumn{1}{|c|}{ References } \\
\hline 1 & Abu Ghusun -Baranes basins & 4.089 & 2.911 & The present study \\
\hline 2 & Quseir-Abu Ghusun basins & 3.89 & 1.75 & Ma Khaled, 1995 \\
\hline 3 & Idfo-Mersa Alam & 3.59 & 1.77 & M.Emam, 1990 \\
\hline 4 & Danffig-Ballas region & 3.82 & 1.85 & Hassan et al, 1982 \\
\hline 5 & Wadis East of Cairo & 3.8 & 2.08 & Said and Beheiri, 1961 \\
\hline 6 & Nile basins of Upper Egypt & 3.5 & $0.5-2.05$ & Yehia, 1983 \\
\hline 7 & Gulf of Suez & 3.5 & 3.5 & Yousef et a1, 1971. \\
\hline 8 & Wadi Degla & ----- & 1.38 & Abdella et al. , 1977 \\
\hline 9 & Wadi Tih & ----- & 1.9 & Abdella et al. , 1977 \\
\hline 10 & U.S. & 3.5 & 3.5 & Charly, 1971 \\
\hline
\end{tabular}

One of the most important measurements of the areal aspects of basins is the drainage density; because of its implication for runoff and climate. The average density for the 7 studied basins under investigation is (2.911). This low density is comparable to the densities obtained for some basins in Egypt; shows a summary of drainage density for Ex-studied basins (using the same scale of the maps).

The climatic implications of the drainage density concluded that the drainage density tends to be highest, in semi arid, lowest in humid temperate region and to be low in arid region. The stream frequency $(\mathrm{F})$ of the studied basins revealed that it ranges from 1.28 to 5.54 with an average of 3.471 reflecting high relief impermeable subsurface materials and sparse vegetations.

In general, both the drainage density and stream frequency are high, suggesting that these drainage networks was formed under semi arid climatic conditions, and give more possibilities for collection of surface runoff. Major structural events took place namely the rift faulting of the Red Sea system associated with the parching of the Precambrian belt, with its sedimentary cover especially at the central part of the area. The final stage of the geomorphic features was the erosion of the major landforms ranges from Pliocene up to the present time. Determination of the two parameters; stream frequency and drainage density in the area of study revealed that both are low, suggesting that the wadi network was subjected during this period to arid climatic conditions.

It must be noted here that stream density and frequency are also controlled structurally and lithologically. Also, it is noticed that the wide variations acquire a drainage density from 2.49 to 3.90 and stream frequency from 1.28 to 5.54 and reflect distinct areas differentiation by lithological variations. It must be mentioned that the drainage pattern represented in Miocene sediments differ from that of basement localities as well as the Nubian sandstones. The structural factors (faulting, folding ...etc.) are also of considerable importance. 
As both drainage density and frequency are high, the surface runoff is expected. At the same time the elongation ratio $(\mathrm{Re})$ denotes elongated basins, which indicates longer period of runoffs, resulting in a replenishment of the groundwater, especially in the area of the sedimentary aquifers. Under such conditions, the construction of barriers becomes more useful to increase the groundwater recharges to the aquifers.

Managing the hydrographic basins is the best way to avoid risk along the coastal area. The appropriate flood control approach is to open as much space as possible to accommodate stream overflow, the other important thing in the open approach is to ensure free passage of water to the sea. A flood water management system may be established, this can be accomplished through building dams by accumulating boulders of weathering products without cementation, these dams have to be constructed at narrow parts of gentle slope courses of the chosen small basins. The study proposed a protection dam sites for the investigated basins.

Hydrogeologically, the groundwater exists under unconfined condition. The groundwater aquifers along the investigated wadi suffer from lacking of recharge and continued dryness period and over pumping activities which appears as lowering of the depth to water in all water wells i. e. Ranga wells, Haratreit well, El Reidi well, Abu Qurayyah well or Taww wells. For these, it is not recommended to drill new groundwater wells in the upstream area.

The suitable groundwater occurrences are detected at sites where the groundwater aquifer attains a reasonable thickness of saturated wadi fills and fractured basement. Accordingly, the most suitable areas for groundwater aquifers are the sites of the down stream portions of these basins and the morpho-tectonic depressions.

\section{CONCLUSION}

The present study deals with the application of the geomorphologic analyses, and hydrogeological to evaluate the groundwater potentiality of the area. That area lies at the southern part of the Eastern Desert of Egypt, between the Red Sea coast and the surface water divide at the west. The present study deals with evaluation of water resources of seven hydrogeologic basins in the area between Abu Ghusun and Bernice. These basins from north to south are Um Al Abas, Abu Ghusun, wadi Ranga, El Reidi, Khashir, Lahami and Mukhit basins.

The average drainage density for the seven studied basins under investigation is (2.911). The basins divided according to the degree of hazard (floods) and the potentiality of water storage accomplished through two curves, the first curve explains the relation between the drainage frequency and the bifurcation ratio and the second explains the relation between the drainage density and the bifurcation ratio. Most basins locate in area that express low groundwater potentialities and high flooding possibilities, the other locates in area that express an area of moderate groundwater potentialities and flooding possibilities.

General hydrogeological units the groundwater in the study area, is from two types of aquifers that are vertically arranged and passed upon age assignment, lithological and hydrogeological characters of the rock units. These are:

I. Aquitard fractured Precambrian basement rocks [fractured Metamorphic Rocks (5 wells)fractured plutonic rocks (15 wells)- fractured Hammamat rocks ( 2 wells)]

II. Sedimentary water bearing aquifers: [Miocene sandstone water-bearing aquifer ( 5 wells), Costal Miocene coral reef aquifer (4 wells), Quaternary and Pleistocene deposits (6 wells)]

Some recommendations are suggested to develop the groundwater resources in the area: 
1. The full utilization of the water of the wells by collecting in reservoirs at their places for redistribution.

2. The exploratory drilling is recommended in the promising sites in every wadi all over the area of study.

3. Earth and concrete dams should be constructed in the proper sites along the drainage nets of the wadis to conserve the surface water and to redistribute the flood water to recharges the shallow aquifers. These barriers and dams minimize the danger of the floods that attack buildings, roads and projects.

4. Arithmetical modeling for the water bearing formation is vital for suggesting the suitable scientific management.

\section{REFERENCES}

Abdel Monem, A. A. (2005). "Overview of the characteristics of geomorphological and hydrogeological characteristics of the Eastern Desert of Egypt." Hydrogeology Journal, Springer; Berlin, 13 (2): 416-425.

Abull Izz, M. S. (1963): Landforms of Egypt: American Univ. Cairo.

AFE and UNESCO, (1963): The development of groundwater resources with special reference to delatic areas, United Nations, New York.

Akkad, M. K. and El Ramly, M. F.(1960): Rocks of the central Eastern Desert. Geol. Surv. of Egypt.

Akkad, M.K. and Dardir. A. A. (1966): Geology of the Red Sea coast between Ras Shagar and Mersa Alam. Geol. Surv. of Egypt.

Al Abasery A.A. and Khaled M.A. (2004): "Geophysical exploration for the groundwater possibilities in Wadi El Rahba, Eastern Desert, Egypt". Egyptian Geophysical Society EGS Journal, 3 (1): 99-108.

Aggour, T.A. and Sadek, M.A. (2001): The recharge mechanism of some cases of the different groundwater aquifers, Eastern Desert, Egypt" Bull. Fac. Science, Mansoura Univ.; 28 (1): 43-78

Ball, J., (1912): The topography and geology of south Eastern Desert of Egypt. survey Department, Cairo.

Beadnel, H.J.(1924): Report on the geology of the Red Sea coast between Quseir and Wadi Ranga. Petrolum Res. Bull., No.13. Surv. Dept. Egypt.

Bedwen settlement project (2004-2005): "Geological, Geophysical and hydrogeological studies on some selected wadies in the Eastern Desert, Egypt” Desert Research Center, Internal report.

Charley, R. J. (1971): The drainage basin as a fandamntal geomorphic unit. In: Introduction to fluival processes. R.charley, pp.29-52. Mechnen. London.

Conoco Coral, (1987): Geological map of Bernice: 500,000: Egyptian General Petroleum Corp., Cairo.

Desert Research Center (1984-1990): Progressive reports submitted to mineral, Petroleum, Groundwater Assessment Project (MAPGAP), Inte. reports.

ECAFE and UNESCO. (1963): The development of groundwater resources with special reference to delatic areas, United Nations. New York.

Egyptian Mineral Resources Authority EMRA (2005): Unpublished report for the tourism development authority "Appendix report of the second stage of mechanical drilling" pp. 1-27.

El Ramly, M. F. (1972): A new geological map of the basement rocks in East and Southwest of Egypt. Annals of Geol. Surv. Egypt 2 : 1-18.

El- Shazly, M. E. (1977): The geology of the Egyptian Region. The ocean basins and margins. Vol. 4A (plenum press, New York and London). 
El- Shazly, M. E. (1982): The Red Sea region. The Ocean Basins and Margins, Vol.6, plenum press, New York and London (pp. 205 - 239).

El Tamamy A.M.M. and Willium A. Sauk (2010): Exploration of the groundwater aquifers in the downstream of Wadi Abu Ghusun, South Eastern Desert, Red Sea, Egypt, using geophysical techniques. J. Applied Geophys., 9 (1) : 95-116.

Ismail, Y.L.; Othman, A.; Adel, Abd El Latif, R.M. and Ahmed, K.A. (2010): Impact of flash flood on development potentials of Wadi Abu Ghusun, Eastern Desert, Egypt. Kuwait J. Sci. Eng. 37 (2A) :111-134.

Kahled, M.A. (1995): "Geological and geophysical investigations for groundwater potentialities in El Quseir-Abu Ghusun area, south of the Eastern Desert, Egypt" M. Sc. Thesis, Fac. of Sci., Cairo Univ. 191 pp.

Khaled, M.A. (2011): "Geophysical study for the groundwater potentiality for the upstream part of Wadi El Kharit-South Eastern Desert-Egypt". The Egyptian Geophy. Soc. (EGS) Journal, Egypt. 9 (1) : 155-167.

Horton, R. E. (1935): Drainage basin characteristics: Trans. Am. Geophs. Union, 13: $350-361$.

Horton, R, E. (1945): Erosion development of streams and their drainage basin, hydrogeological approach to quantitative morphology. Bull. Geol. Soc. Am., 56: $275-370$.

Makram, F. S. (1993): Hydrogeological and hydrogeochemical studies on some localities in south Eastern Desert, Egypt. Ph.D thesis. Fac. of Sci., Suez Canal Univ., Egypt. 260 pp.

Hume, W.E. (1907): A preliminary report on the geology of the Eastern Desert of Egypt, between Lat. 22N and 25 N. Egypt. Surv. Dep., Cairo, 72 pp.

Hume, W.F (1937): Geology of Egypt, Vol. II, part III. The Minerals of economic value. The Sriv. Egypt. pp.939-986.

Mc Cullagh, P.C. (1978): Modern concepts in geomorphology. Science in geography (6) Oxford Univ. Press.

Milton, M.A. (1958): Geometeric properties of nature drainage system and their representation in an phase space. J. Geol. 66: 35-54.

Morcos, M. B. (1977): Photogeologic studies on the Precambrian rocks of the central Eastern Desert of Egypt. unpublished ph.D. Thesis Cairo Univ. 269 pp.

National Academy of Science and National Academy of Engineering (1972): Water quality criteria. Protection Agency; Washington. D.C., pp.1-594.

Said, R., (1962): The geology of Egypt. Elsevier publishing Co., Amsterdam, New York, $337 \mathrm{pp}$.

Said, R. (1990): “The geology of Egypt” A.A. Balkema-Rotterdam-Brookfield.

Samir, A. and Shibl, A. (1982): Geophysical exploration for the groundwater at Wadi Lahmy, South Easter Desert, Egypt, Egyptian Geological Survey and Mining Authority. 12: 185-191.

Samuel, M.D. and Saleeb- Rofaiel, (1977): Lithostratigraphy and petrographic analysis of Neogene sediments at Abu Ghusun, Um Mahra area, Red Sea Coast, Egypt. Beitr. Zur Lithologie, Freibarg. Forch., 323(c); 47-56.

Shumm S.A. (1956): Evaluation of drainage system and slopes in bed land at perth Amboy. New Jersy, Bull. Geol. Soc. Am. 67: 597- 646.

Strahler, A. N., (1952): Hypsometric (area-altitude) analysis of erosional topography: Geol. Soc. America Bull., 63: 1117-1142.

Strahler A.N. (1964): Quantitative geomorphology of drainage basins and channel networks. Handbook of Applied Hydrology. Section II. 
Tahoon, M.A. (2011): "Hydrogeological and environmental study in the area between Marsa Alam and Baranes- Red Sea, Egypt. Ph.D. Thesis. Fac. of Sci., South Valley Univ., Egypt.

Tourism Authority (2005); Lithological description and hydrogeologic data of the drilled well. internal report.

Wahballa, A.M.; Mansour, A.M. and Tahoon M.A. (2010): Geological and geochemical studies on the underground water characteristics in the area between Marsa Alam and Baranees-Red Sea- Egypt. Egyptian Journal of Aquatic research. 36 (1): 21 pp.

World Food Program "WFP" (2004): An internal report No.3, (final report) on groundwater exploration in the southeastern part of the Red Sea governorate, Egypt. 58 pp.

\section{ARABIC SUMMARY}

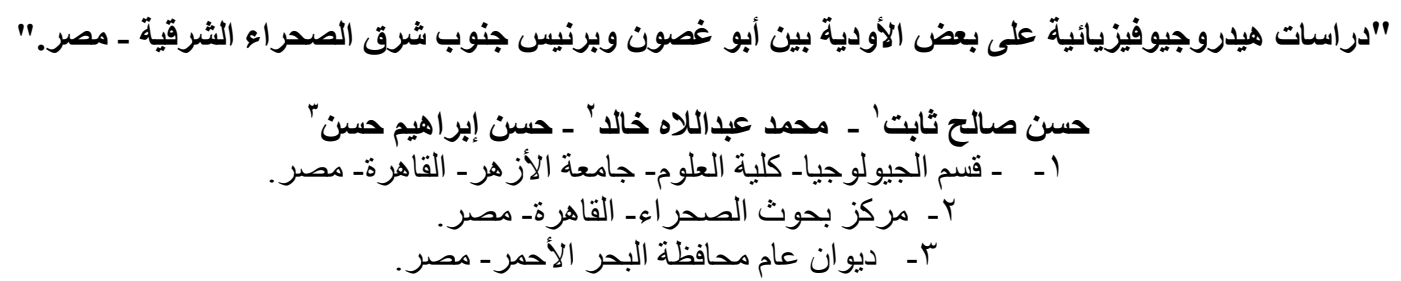

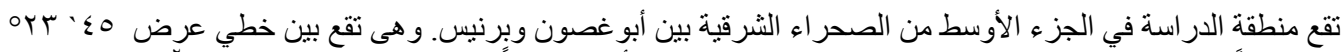

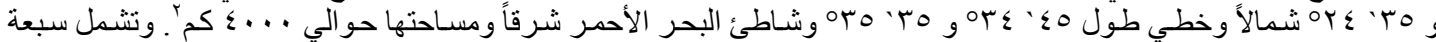

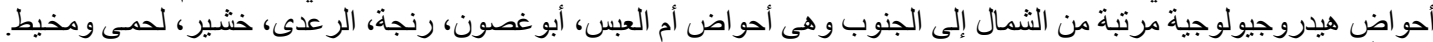

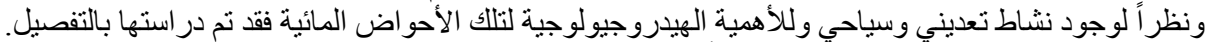

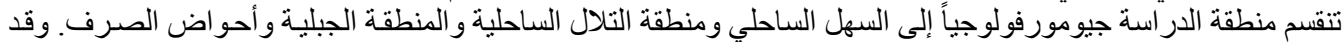

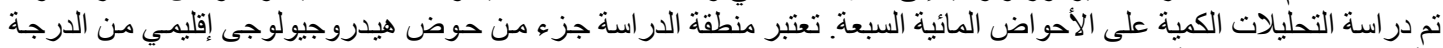

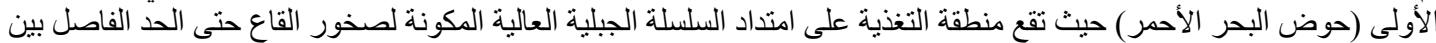

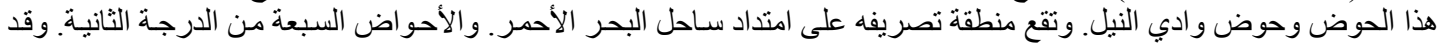

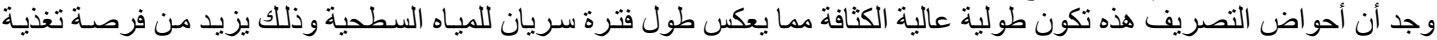

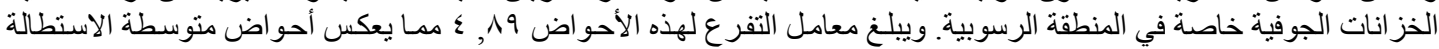

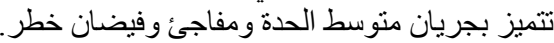

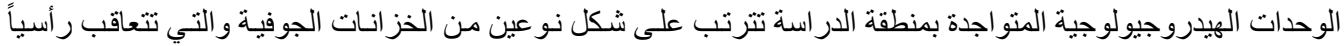

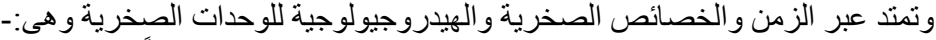

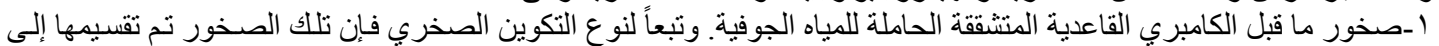

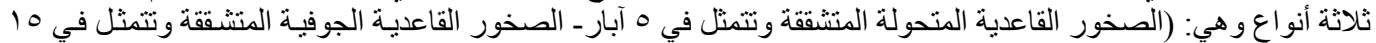

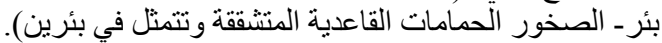

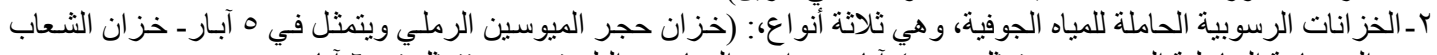

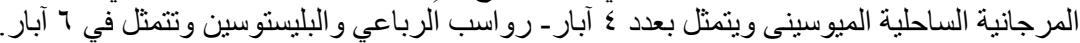

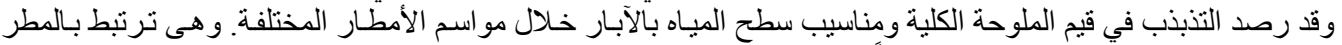

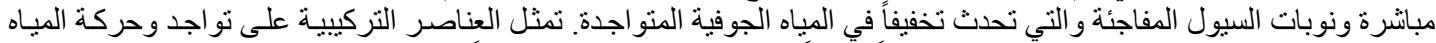

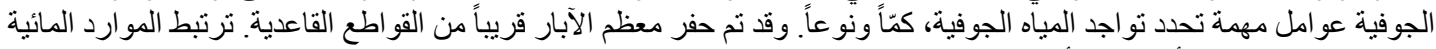

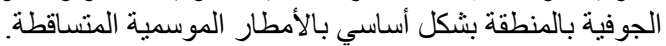

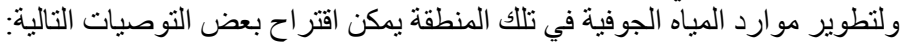

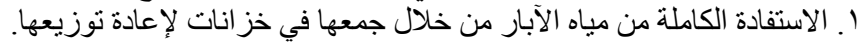

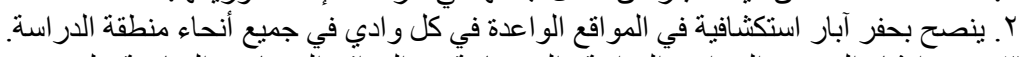

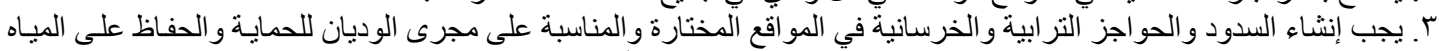

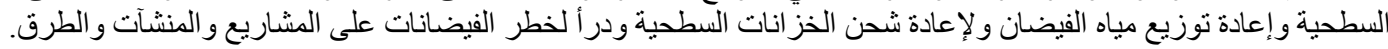

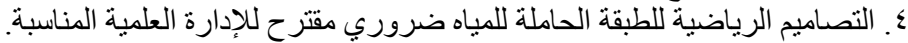

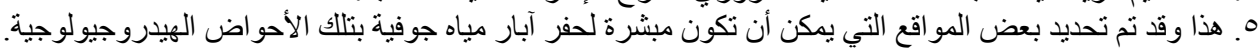

